\title{
La deuda judía del nacional-catolicismo español y del nativismo vasco
}

\section{The Jewish Debt Owed by Spanish National- Catholicism and Basque Nativism}

\author{
Juan Aranzadi \\ Departamento de Antropología Social y Cultural \\ Universidad Nacional de Educación a Distancia (UNED)
}

\section{RESUMEN}

Tras apuntar a los orígenes sociales y políticos del nacionalismo vasco en sus libros El milenarismo vasco (1981) y El escudo de Arquíloco (2001), el autor plantea aquí que la raíz histórica e ideológica última de la definición castiza, "religioso-racial", de la identidad española (la que alcanza su expresión más extrema y acabada con el franquismo) es la misma que la de la etnicidad vizcaína a partir del siglo XVI. Esta raíz ha de buscarse en el pensamiento rabínico acerca de la identidad judía, surgido en el exilio babilónico tras la destrucción del reino de Judá en el siglo VI a. C., como revela una parte significativa del Antiguo Testamento.

Palabras clave: Nativismo, Nacionalismo, Judaísmo, Catolicismo, Casta, Etnicidad, Limpieza de sangre, España, País Vasco.

\section{SUMMARY}

After identifying the social and political origins of Basque nationalism in his books El milenarismo vasco (1981) and El escudo de Arquiloco (2001), the author argues here that the ultimate historical and ideological source for the pure-blooded, "socio-religious" understanding of Spanish identity (which reached its most extreme and finished expression under Franco's dictatorship) is the same as that of Biscayan ethnicity from the $16^{\text {th }}$ century onwards. This source must be found in the rabbinical thought about Jewish identity that emerged in the Babylonian exile after the destruction of the kingdom of Judea in the $6^{\text {th }}$ century B. C. and is revealed by a significant part of the Old Testament.

Key Words: Nativism, Nationalism, Judaism, Catholicism, Caste, Ethnicity, Blood Cleansing, Spain, Basque Country. 
Lo que pretendo sugerir al hablar de la "deuda judía" del nacional-catolicismo español y del nativismo vasco es que ambos movimientos tienen en común - paradójicamente, puesto que se oponen entre sí- una importante deuda ideológica, simbólica y práctica con el judaísmo, al que ambos rechazan.

Esa deuda consiste en el modo específicamente judío de concebir y definir, a partir del siglo XVI, tanto la etnicidad española como la etnicidad vizcaína, sustrato simbólico y núcleo ideológico, tanto la una como la otra, de los muy posteriores nacionalismos español y vasco.

La tesis que voy a proponer puede subdividirse en tres, la primera de las cuales es la central y la que preferentemente voy a desarrollar en este ensayo:

1. La concepción rabínica de la identidad judía es el origen histórico y el fundamento ideológico de la definición castiza, "religioso-racial", de la identidad española y de la etnicidad vizcaína a partir del siglo XVI.

2. La definición católica de la identidad española —es decir, la identificación inquisitorial de la etnicidad española con la condición castiza de "cristiano viejo", concebida como esencia "religioso-racial" - constituye el núcleo simbólico y el fundamento ideológico del nacional-catolicismo español, que alcanza su forma extrema y acabada con el franquismo.

3. El nacionalismo vasco de Sabino Arana, cuya formulación inicial fue explícitamente bizkaitarra, constituyó una reacción nativista a la quiebra histórica (tras la abolición de los Fueros, un brutal desarrollo industrial y una inmigración masiva) de la previa integración armónica, en la España del Antiguo Régimen, de la población vizcaína étnicamente diferenciada de la española por la posesión de hidalguía colectiva. Y esta temprana modalidad de etnicidad vizcaina - forjada también a partir del siglo XVI- no es sino una variante, una radicalización, una "vuelta de tuerca", de la identidad española inquisitorial: la "raza vasca" de Sabino Arana proviene directamente del español castizo "cristiano viejo" y el maketo de los nacionalistas vascos es una metamorfosis del moro de los nacionalistas españoles.

Tanto en Milenarismo vasco (1981) como en Sangre Vasca, primer tomo de El Escudo de Arquíloco. Sobre mesías, mártires y terroristas (2001), he dedicado un considerable número de páginas a desarrollar y justificar la tercera de estas sub-tesis, sobre algunos de cuyos aspectos volveré en este ensayo, aunque en él me centraré, como ya he dicho, en la primera.

No obstante, una adecuada valoración de su relevancia exige, me parece, antes de entrar en el meollo del asunto, aclarar algunos puntos sobre 
dos cuestiones importantes que configuran el marco en que dicha sub-tesis ha de ser interpretada:

A. Las relaciones entre la etnicidad española "católico-racial" y el nacionalismo español.

B. La concepción judía de la etnicidad.

\section{A. Breves nOtas SOBRE EL NACIONALISMO ESPAÑOL}

El papel nuclear que la etnicidad española "católico-racial" juega en el nacionalismo español deriva del siguiente hecho histórico que aquí me limito a enunciar: la única variedad ideológica de nacionalismo español que ha logrado un arraigo social de masas es el nacional-catolicismo, especialmente en su formulación franquista.

Esta tesis se basa en otras varias que paso a enumerar:

1. Hasta comienzos del siglo XIX no se puede hablar de nacionalismo español en el sentido estricto de nacionalismo político (entendido como una ideología que sintetiza la idea tradicional de Patria con la idea moderna de soberanía popular, de soberanía de un Pueblo-Nación concebido como demos y/o como volk), si bien es cierto que la moderna idea nacionalista de España como Nación se elabora con ingredientes simbólicos, políticos y étnicos provenientes de ideas previas tradicionales de España como Reino Católico y como Imperio Católico, y tiene su fundamento ideológico en la definición "católico-racial" de la etnicidad española configurada desde el siglo XVI.

2. La idea nacionalista de España elaborada por el liberalismo español del siglo XIX no llega nunca a romper por completo con la idea católica de España, con la idea de España como una Nación Católica y/o como un Imperio Católico: la Constitución liberal de Cádiz proclamaba (artículo 12) que "la Religión de la nación Española es y siempre será la única verdadera religión, la religión Católica, apostólica y Romana”, y el Concordato de 1851 (reconocido por la Constitución liberal de 1876, que estuvo en vigor hasta la proclamación de la Segunda República en 1931) reconocía que "la religión Católica, apostólica, Romana que, con exclusión de cualquier otro culto, sigue siendo la única religión de la nación Española, disfrutará para siempre de todos los derechos y prerrogativas de que debe gozar de acuerdo con la ley de Dios y con lo que se ha acordado por los cánones sagrados". Lo que se produjo en España en el siglo XIX no fue tanto una batalla ideológica entre liberalismo y catolicismo cuanto una lucha política por el poder y la riqueza de la Iglesia (que era, el Ejército aparte, el único aparato estatal del Antiguo Régimen) entre el clero y la jerarquía católica por una 
parte y, por la otra, una emergente elite social que, si bien se definía como liberal, era además católica en su casi totalidad.

3. Hasta bien entrado el siglo XIX, las diferentes y concurrentes ideas nacionalistas de España (la idea liberal, la idea republicana - jacobina o federal - y la idea nacional-católica de la derecha) eran propiedad exclusiva de una elite letrada y no tenían la más mínima posibilidad de acceder y encontrar arraigo en la consciencia y la imaginación de una población cuyo índice de analfabetismo estaba cerca del 80\% a finales del siglo XIX. La pastoral de la Iglesia y la participación en el proceso ritual católico fueron, hasta las primeras décadas del siglo xx, los únicos medios que el Estado "español" tenía para influir ideológica y simbólicamente en la inmensa mayoría de la población. El Estado español "nacional" del siglo xix carecía de los dos principales instrumentos políticos para inocular en la población la ideología y el simbolismo nacionalistas: la alfabetización masiva en la escuela pública y el servicio militar obligatorio. Además, el hecho de que en España no se produjeran guerras en defensa de la Nación que movilizaran militarmente a la población (ni la tardíamente llamada Guerra de la Independencia ni, menos aún, las guerras coloniales para defender los restos del Imperio pueden considerarse como tales) privaron a la población española de ese profundo sentido de pertenencia a una comunidad nacional imaginaria que sólo puede llegar a generar la "guerra nacional", es decir la experiencia de "matar y morir por la Patria", la experiencia compartida de afrontar en común el riesgo de la muerte propia y de los más próximos a manos de aquellos categorizados como enemigos de la Nación.

4. Otro importante vehículo para la "nacionalización de las masas", la participación del "pueblo" en la política "nacional", se produjo en España, durante el primer tercio del siglo xx, bajo la poderosa influencia de ideologías revolucionarias para las cuales la Nación, cualquier posible idea de España como "comunidad nacional", jugaba un papel movilizador insignificante y estaba claramente subordinado a las ideas de Revolución, de Clase Obrera, de Proletariado, de pueblo oprimido y de "comunidad de trabajadores". Tanto los anarquistas como los comunistas y los socialistas eran más internacionalistas que nacionalistas, y el hecho de que España no se viera envuelta en la Primera Guerra Mundial evitó a los socialistas españoles la traumática elección entre la Nación y la Clase Obrera a que hubieron de enfrentarse sus camaradas de la II Internacional. Todo ello ha provocado que la única modalidad de nacionalismo español que ha logrado hasta ahora un arraigo social profundo y un apoyo de masas sea el nacional-catolicismo, especialmente en su versión franquista tras la victoria en la Guerra Civil y 36 años de adoctrinamiento totalitario. Durante ese largo período histórico, el nacional-catolicismo franquista mantuvo viva y plenamente vigente 
la etnicidad española, labrada en el siglo xvI, y generó una profunda mixtificación retrospectiva de la evolución histórica de los significados de palabras como "España" y "españoles" acerca de la cual nos detendremos en otra ocasión.

\section{B. ¿QUÉ ENTIENDO POR "DEUDA JUDÍA”? JUDAÍSMO, ETNICIDAD Y SIONISMO}

A continuación intentaré aclarar en qué consiste, en mi opinión, ese modo específicamente judío de concebir la etnicidad — de definir la identidad del "pueblo judío" - que influye poderosamente en la configuración de la etnicidad "española" y "vasca".

Para entender la identidad judía tal y como históricamente la define el judaísmo en general y los rabinos "ortodoxos" en particular, así como las relaciones que en el actual Estado de Israel se registran entre la ciudadanía israelí y la identidad judía, es preciso tener en cuenta una serie de datos históricos, políticos e ideológicos acerca del judaísmo y del Estado de Israel que a continuación resumo:

1. La distinción entre judio e israeli en el actual Estado de Israel (pues hay ciudadanos israelíes que no son judíos, sino cristianos, musulmanes, árabes, beduinos o drusos) tiene claros antecedentes bíblicos. Con independencia de que se conceda un valor histórico o mítico-legendario a los relatos bíblicos del Pentateuco cristiano o Torá judía (cuya recopilación canónica fue obra de Esdras y Nehemías en el siglo V a. C.) la Biblia establece, desde Génesis hasta Crónicas, una clara distinción entre "israelita" y "judío":

a. El "pueblo de Israel", al que Yahvé eligió como su pueblo y con el que estableció su Alianza, estaba formado por los descendientes patrilineales de Jacob-Israel; es decir, por los doce clanes o "tribus" (en hebreo, shebet) que postulaban descender de los doce hijos que tuvo Jacob con sus dos primas cruzadas matrilaterales, Lía y Raquel. Uno de esos hijos, el que dará origen al etnónimo "judíos", era Judá;

b. Aunque la línea principal del relato bíblico sobre el establecimiento en Canaán del "pueblo de Israel" y su apropiación de la "tierra prometida" por Yahvé es un relato de conflicto bélico y de dominación y exterminio de los pueblos cananeos por orden de Yahvé y bajo su protección, en paralelo discurre otro relato menos explícito de alianzas políticas y matrimoniales del "pueblo de Israel" con los pobladores previos de Canaán y de incumplimientos flagrantes de su Alianza con Yahvé. Las constantes denuncias de los Profetas son el mejor testimonio de que - a la luz de la imagen bíblica - el yahvismo que reivindicará como suyo el posterior judaísmo estaba muy lejos de disfrutar de la hegemonía "religiosa" en el Reino unitario 
de David y Salomón y en los posteriores Reinos divididos de Israel y de Judá. Tanto la ausencia de prohibición de matrimonios mixtos como el diversificado tratamiento por la Torá de las relaciones de los "israelitas" con los "extranjeros" (zarim o nokhrim) y con los "residentes foráneos" (gerim) atestigua la inexistencia en el Israel bíblico de la posterior separación y oposición radical entre "judíos" y "gentiles" (goyim).

c. Según el relato bíblico, tras la muerte del Rey Salomón —quien había hecho edificar el Primer Templo- el "pueblo de Israel" se dividió políticamente en dos Reinos: el de Judá al sur, con capital en Jerusalén, constituido por los descendientes patrilineales de Judá y de Benjamín, y el de Israel al norte, formado por los descendientes patrilineales de los otros diez hijos de Jacob que no reconocían el Templo de Jerusalén como centro de su culto. El Reino de Israel, cuya última capital fue Samaria (origen del etnónimo "samaritano") fue conquistado por el Imperio Asirio el año 722 a. C. y la mayoría de su población forzada a exiliarse. También fue forzada a exiliarse, siglo y medio más tarde (589 a. C.), la mayoría de la población del Reino de Judá, tras su conquista por el Imperio Babilónico y la consiguiente destrucción del Primer Templo.

d. El posterior judaísmo rabínico y quienes más adelante se consideran a sí mismos "judíos" reivindican descender de la población del Reino de Judá exiliada en Babilonia —y, por lo tanto, a través de ella, de Judá y Benjamín- y se refieren a los descendientes de los otros diez hijos de Jacob, exiliados dos siglos antes, como "las diez tribus perdidas". Al postular que estas diez tribus desaparecieron sin dejar rastro, los que se consideran descendientes de los exiliados del Reino de Judá — es decir, los "judíos”- reivindican que ellos son los únicos descendientes vivos del antiguo "pueblo de Israel", si bien no faltan movimientos y grupos político-religiosos, como los Israelitas Británicos y los Mormones, que les disputan ese derecho al reivindicarse como descendientes de las diez tribus perdidas de Israel.

2. Los pilares del "judaísmo" del Segundo Templo y de lo que más tarde será el judaísmo rabínico los elabora la comunidad "judía" exiliada en Babilonia: al servicio de una organización ritual de todos los aspectos de la existencia humana bajo el imperio de la Ley escrita (la Torá) —organización que actúa como garantía de preservación étnica- se sistematizan entonces algunos de los rasgos distintivos del judaísmo futuro (la circuncisión, el Shabbat, el ciclo litúrgico, las reglas de pureza, de limpieza, de dieta, de endogamia, etc.) y empieza a desarrollarse, bajo la forma de comentarios a la Torá, la Ley oral cuya sistematización escrita será el Talmud. El retorno de estos exiliados a Judea, bajo la dirección de Esdras y Nehemías y con el apoyo de los emperadores persas, de Ciro primero y de Darío después, 
impondrá — en el marco de una remodelación política de la región- esa organización "religiosa" en torno al Segundo Templo reconstruido, a la que se resistieron sin éxito los descendientes de los pobladores de los antiguos Reinos de Israel y de Judá — los "judíos” pobres (am-ha-rez), samaritanos y edomitas- que habían permanecido en su tierra. El modo en que Esdras y Nehemías trataron de resolver los problemas sociales planteados por la "idolatría", los matrimonios mixtos y las disputas por la propiedad de la tierra iba a dejar una impronta indeleble en la futura definición de la identidad judía: al diagnosticar la exogamia como origen y raíz de la idolatría, invalidaron los matrimonios mixtos, impusieron la endogamia judía (la prohibición de casarse "fuera", con no-judíos) como sinónimo de fidelidad a Yahvé y excluyeron a los no-judíos de la propiedad de la "tierra prometida” por Yahvé. Desde entonces, la Alianza con Yahvé les prohíbe a los judíos la alianza matrimonial con otros pueblos, y en esa prohibición se halla implícita la definición genealógica ("biológica") del judío como descendiente de madre judía. La mal llamada "matrilinealidad" de la identidad judía no es sino síntoma y consecuencia del imperativo de endogamia, que afecta fundamentalmente a los varones judíos, pues que una mujer judía se case con un varón no-judío fue durante mucho tiempo $-\mathrm{y}$ sigue siéndolo entre judíos "ortodoxos" - simplemente impensable: nacer de madre judía es la condición de posibilidad de ser judío, pero la identidad social del judío dentro de la comunidad judía ha tenido siempre y sigue teniendo un importante sesgo "patrilineal".

3. Entre la restauración del Segundo Templo por Esdras y Nehemías y su destrucción por Tito el año 71 d. C., el "judaísmo" se diversifica ideológica y prácticamente sobre la base común de la aceptación de la Torá y de sus exigencias rituales etnogénicas, como la endo-comensalidad y la endogamia: las polémicas ideológicas y divergencias prácticas entre fariseos, saduceos, esenios y zelotes acerca, fundamentalmente, de la prioridad del Templo o de la Sinagoga, de la aceptación o no de la Ley oral además de la Ley escrita, de las interpretaciones del Mesías y la inminencia o no de su llegada y de las implicaciones políticas y prácticas del mesianismo, se resolvieron históricamente con la destrucción del Templo, la derrota militar de los zelotes primero (73 d. C.) y del "mesías" Bar Koshba después (132 d. C.) y el final predominio de la corriente farisea. Con independencia por tanto de cómo se interpreten y valoren sus invocados antecedentes históricos e ideológicos, lo que conocemos actualmente como judaísmo, el judaísmo rabínico posterior a la muerte de Cristo, es un movimiento socio-religioso que se configura tras la destrucción de Jerusalén, en la llamada diáspora judía del Imperio Romano, en continuidad ideológica con la corriente farisea y fundado sobre tres pilares: la autoridad social de los rabinos, la autoridad 
ideológica del Talmud (la "Ley oral" finalmente recopilada por escrito) y la concentración de la comunidad en torno a la Sinagoga.

4. Desde el siglo II d. C. hasta hoy, durante cerca de 2.000 años, y con independencia de cómo les definieran y les juzgaran los "gentiles" entre los que vivían (y en particular, los cristianos medievales judeófobos y los europeos modernos antisemitas que con frecuencia creciente les perseguían y les expulsaban, y que, finalmente, en la Alemania nazi, casi lograron exterminarlos) los judíos han tenido y siguen teniendo, en palabras de Akiva Orr (1994: 8-9),

una autodefinición clara, incuestionada y carente de ambigüedad de su identidad grupal: "identidad judía" significa la práctica de reglas religiosas para la conducta en la vida. Esas reglas se conocen como mitzvot (mandamientos religiosos), una derivación de la palabra hebrea tzav (mandamiento). La "identidad judía" consistía en la práctica diaria de los mitzvot. Cualquiera que los practicara diariamente era y es considerado como judío por él mismo y por los otros (judíos y no-judíos). Nadie ha cuestionado nunca la afirmación de que "los que practican los mitzvot son judíos". Ésta es la única definición de "identidad judía" que nunca ha sido desafiada por nadie. Es incuestionable. No hay un solo ejemplo de una persona que practique los mitzvot y que no sea judía. Esta definición no es la definición religiosa oficial (que es una definición circular, basada en la "identidad judía" de la madre). Es una definición antropológica propuesta por el autor de este ensayo. Todas las demás definiciones de la "judeidad" o "condición judía" - incluidas las definiciones religiosas - han sido desafiadas y discutidas, son cuestionadas, y carecen de aceptación general.

La definición ideológica "ortodoxa" mínima de la identidad judía como "descendencia de madre judía” no es sino una explicitación de la importancia fundamental del imperativo de endogamia entre esos mitzvot. Es decir, la definición religioso-ritual de la identidad judía fundamenta y genera el criterio genealógico-racial de etnicidad con arreglo al cual se definirá la identidad del "pueblo judío" primero y de los pueblos "español"y "vasco" después.

5. El judaísmo que durante 2.000 años ha definido la "identidad judía" es, por lo tanto, fundamentalmente, una ortopraxis, mucho más despreocupada que el cristianismo por la ortodoxia doctrinal: no hay, entre los rabinos, organización clerical jerárquica ni autoridad doctrinal alguna semejante al Papado, y distintas corrientes ideológicas del judaísmo ortopráctico pueden ofrecer, y de hecho ofrecen, interpretaciones teológicas diametralmente opuestas de una misma práctica ritual, idéntica y escrupulosamente ejecutada por todos. Las corrientes y ramas de lo que, desde una perspectiva exterior cristiano-céntrica, se denomina actualmente "judaísmo ortodoxo" (incluidas aquellas sectas ambiguamente llamadas "ultra-ortodoxas") registran entre sí innumerables diferencias teológicas y doctrinales - comprendiendo, entre esas diferencias, actitudes muy distintas, hasta contrapuestas, 
ante el sionismo y el Estado de Israel, desde su rechazo como sacrílego hasta su sacralización mesiánica- pero se hallan unidas por un común y escrupuloso respeto a los mitzvot. Ese respeto práctico cotidiano de los mitzvot, especialmente de aquellos que se refieren a la comida kosher, a la comensalidad y al matrimonio endogámico, genera una auténtica frontera étnica con los "gentiles": el judaísmo ortopráctico es la sacralización teocéntrica de una extrema ritualización de la vida cotidiana que actúa socialmente como frontera étnica con los "gentiles".

6. Como reacción a la Modernidad (a la Reforma protestante, a la Ilustración, a la Revolución Francesa y a la emancipación legal de los judíos) y a la consiguiente reformulación de la actitud de los "gentiles" hacia unos "judíos" redefinidos por los antisemitas como una "raza" o como una "nación", se produjeron en distintos sectores de la comunidad judía europea diversos intentos de adaptación y de asimilación a las nuevas condiciones del "mundo moderno":

A. Algunas de esas "adaptaciones" no quisieron renunciar al rabinato ni a la Sinagoga ni al Talmud, pero procedieron a reformar en mayor o menor grado los mitzvot y a relajar notablemente el rigor en su cumplimiento, diluyendo así en grado variable la frontera práctica y ritual cotidiana que separaba étnicamente a "judíos" y "gentiles". Los "grupos adaptacionistas" resultantes de este movimiento - lo que se conoce como Judaísmo Reformado, Conservador y Reconstruccionista - siguen considerándose "judíos" y, aunque ellos no pueden dejar de considerar "judíos" a los judíos ortoprácticos mal llamados ortodoxos, éstos no les corresponden y les consideran a su vez a ellos "malos judíos", "pecadores" que no siguen los mitzvot e incluso, en caso de conversión al cristianismo o al islam, "no-judíos": para responder a ese reproche, a ese rechazo y a esa expulsión de la comunidad judía, los rabinos "adaptacionistas" se vieron, y se ven, obligados a proceder a redefiniciones más laxas de la "identidad judía" que fueron y siguen siendo radicalmente rechazadas por los judíos ortoprácticos. En 1885, por ejemplo, los rabinos reformistas americanos reunidos en la Plataforma de Pittsburg afirmaron que los judíos son una agrupación religiosa, no una nación, y rechazaron el regreso a Sión;

B. Algunos llevaron el movimiento de "adaptación" a la Modernidad hasta la renuncia a la Sinagoga, a la autoridad social de los rabinos y a la autoridad ideológica del Talmud, desembocando en una de estas dos formas de asimilación:

a. La asimilación individual completa, la renuncia voluntaria a la "identidad judía", variablemente favorecida o impedida por la actitud "gentil" y por la mayor o menos fuerza del antisemitismo; y 
b. La asimilación colectiva con arreglo a los parámetros de la ideología nacionalista moderna, es decir la auto-concepción de los judíos como una raza, una nación o un pueblo "como los demás", lo cual obligaba a una re-definición nacionalista de la "identidad judia" emancipada de los rabinos, de la Sinagoga y del Talmud: ésa fue la tarea ideológica que se impuso el sionismo.

7. En las relaciones entre sionismo, judaísmo e identidad judía hay que distinguir varios aspectos:

A. La actitud ideológica del sionismo hacia el judaísmo: los sionistas, mal llamados "judíos laicos", rompen con el judaísmo en la medida en que rechazan la autoridad social, política e ideológica de los rabinos, de la Sinagoga y del Talmud, y no cumplen los mitzvot, pero conservan un grado notable de dependencia con respecto a la teología judía (bíblica y/o talmúdica) en la definición sionista de la nación judía y de la identidad judía, dependencia que varía según dicha definición haga hincapié en la raza (descendencia de madre judía), la lengua (el hebreo), la cultura (rabínica) o la historia (bíblica).

B. La actitud ideológica y práctica del judaísmo ortopráctico (mal llamado "ortodoxo") hacia los sionistas: la mayoría de los rabinos "ortodoxos" (Agudat Israel), desde el nacimiento del sionismo hasta la creación del Estado de Israel, condenaron y rechazaron radicalmente el sionismo por su impío y sacrílego intento de usurpar el lugar de Yahvé en la prometida restauración de Sión. Sólo un grupo ortopráctico minoritario de seguidores del rabino Kook en Palestina (Misrabi) consideró conciliable el judaísmo con el sionismo.

C. Los compromisos prácticos de los líderes sionistas con los rabinos "ortodoxos" en el momento de la creación del Estado de Israel: conscientes los sionistas de la escandalosa inviabilidad de un Estado judio que fuera públicamente condenado por la mayoría de los rabinos como sacrílego, y conscientes los rabinos de los muchos beneficios prácticos que las comunidades judías "ortodoxas" podían obtener de un Estado que les estaría por siempre ideológicamente endeudado, pactaron un régimen de statu quo que se mantiene en el Estado de Israel hasta hoy y cuyas principales manifestaciones son las siguientes:

a. La proclamación, en la Declaración de Independencia, del Estado de Israel como un Estado judio (y no sólo "para los judíos") "fundado en la justicia, la libertad y la paz según el ideal de los profetas de Israel".

b. La definición legal de la "identidad judía", que en Israel concede el derecho automático a la ciudadanía, con arreglo al criterio rabínico 
que considera judío a "todo hijo de madre judía no convertido a otra religión y/o al converso al judaísmo según la Halakha" (lo cual limita las conversiones reconocidas por el Estado de Israel a aquellas, escasas, que reconocen los rabinos "ortodoxos").

c. La concesión exclusiva a los tribunales rabínicos de la competencia sobre "todo lo que concierne al matrimonio y el divorcio de los judíos en Israel [que se efectúan] en virtud de la ley de la Torá" (ley de 1953), lo cual supone la inexistencia del matrimonio civil en Israel y la consiguiente imposibilidad legal, en Israel, del matrimonio entre una persona judía y una no-judía.

d. La existencia legal, en un Estado oficialmente "laico", de múltiples vacíos jurídicos, análogos al que afecta al matrimonio, acerca de espacios sociales regulados por los tribunales rabínicos, y de otros múltiples campos en que ambas jurisdicciones se solapan conflictivamente.

8. Entre las consecuencias sobre la relación entre identidad judía y ciudadanía israelí de ese perdurable statu quo entre sionismo y judaísmo en el Estado de Israel se halla la discriminación étnica pro-judía entre los ciudadanos de Israel y, a la vez, paradójicamente, la problematización y diversificación de la etnicidad judía. Por lo que se refiere a la discriminación étnica, hay que decir lo siguiente: por una parte, el Estado de Israel reconoce como ciudadanos (formalmente) de pleno derecho tanto a quienes el propio Estado define étnicamente como judíos cuanto a los no-judíos, a quienes define étnicamente, por ejemplo, como árabes o como drusos. Pero, por otra parte, la soberanía del Estado se le atribuye en exclusiva al "pueblo judío", formado tanto por los judíos de Israel como por los judíos de la Diáspora, a los que se reconoce, en la Ley del Retorno, el derecho a la ciudadanía israelí con sólo demostrar su "identidad judía" con arreglo al criterio rabínico antedicho. El resultado es que un ciudadano israelí no-judío está excluido, en el Estado del que es formalmente ciudadano, del pueblo soberano de ese Estado, lo que le excluye de facto de una serie de derechos cívicos que formalmente tiene; como, por ejemplo, el derecho a ser propietario de tierra y de la vivienda que sobre esa tierra se construya, puesto que en Israel la casi totalidad de la tierra es propiedad del Estado judio, y éste —en virtud de la asimilación sionista de la ideología rabínica sobre la sacralidad de la tierra judía prometida por Yahvé al pueblo judío- acepta y legaliza la prohibición rabínica de vender tierra judía a un no-judío. Ese derecho a la propiedad de la tierra que un ciudadano israelí no-judío no tiene, lo tiene sin embargo un ciudadano de otro país cualquiera —un "judío de la Diáspora" - cuya "identidad judía" le sea reconocida por el Esta- 
do de Israel. Ahora bien, paradójicamente, aunque el criterio de "identidad judía" que el Estado de Israel utiliza ("es judío el descendiente de madre judía o converso al judaísmo") sea deudor de la ideología rabínica, en la práctica, para los rabinos "ortodoxos", la identidad judía - la condición de miembro de la comunidad judía- está definida por el respeto a los mitzvot, y la inmensa mayoría de aquellos a quienes el Estado de Israel reconoce como judíos son, sin embargo, para los judíos ortoprácticos, sólo "malos judíos", "pecadores", o incluso meros "gentiles que hablan hebreo". El resultado de este embrollo identitario es que aquellos sobre cuya identidad judía no tiene nadie ninguna duda - los judíos ortoprácticos que respetan los mitzvot - no reconocen, en su mayoría, el carácter judio del Estado de Israel, pese a la fuerte deuda ideológica que éste tiene contraída con el judaísmo. Ni reconocen tampoco como judíos a un gran número de ciudadanos israelíes que, sin embargo, sí se consideran a sí mismos judíos y reivindican su "identidad judía", pero que reclaman una "identidad judía" distinta a la basada en el cumplimiento de los mitzvot, una "identidad judía" de carácter lingüístico, cultural o, predominantemente, racial (en tanto que fundada en la descendencia biológica) que, no obstante, resulta ambigua, incierta y problemática a sus propios ojos, y tiende a confundirse con la simple identificación con el Estado de Israel.

Aunque me ha parecido conveniente extenderme hasta el actual Estado de Israel en la exposición de los problemas definitorios de la identidad judía, es obvio que para lo que sigue — la "deuda judía" de la etnicidad española y vizcaína - sólo resulta pertinente lo dicho más arriba acerca de la concepción rabínica temprana de la etnicidad judía.

\section{GÉNESIS DE LA ETNICIDAD "ESPAÑOla" y "VIZCAínA"}

En lo que sigue, me voy a permitir hacer un uso abundante, aunque un tanto libre, de las ideas expuestas en dos libros de la antropóloga belga Christianne Stallaert (1998, 2006) para mostrar la relación entre el criterio judío de etnicidad, el surgimiento de la etnicidad española y el nacimiento de la etnicidad vizcaína en que se apoya el nativismo vasco ${ }^{1}$.

${ }^{1}$ El primero de los libros de Stallaert (1998) hace una interpretación antropológica sui generis de las tesis de Américo Castro, utiliza los resultados de la investigación de un amplio plantel de historiadores (Caro Baroja, Domínguez-Ortiz, Barkai, Bataillon, Benassar, Epalza, García Cárcel, Glick, Maravall, Mitre Fernández, Suárez Fernández y un largo etcétera) y se fundamenta en su propio análisis de fuentes documentales que van desde el siglo XII hasta finales del XV, especialmente de las Siete Partidas, el Fuero Real y los Fueros locales. En lo que sigue, no pretendo aportar ningún dato nuevo; por 
Reducida a lo esencial, mi versión libre de la tesis de Stallaert reza así:

El surgimiento de la etnicidad española (de "los españoles" como grupo étnico diferenciado, con un criterio claro de identidad social, es decir de auto-adscripción y de hetero-adscripción grupal) es un efecto del proceso de transformación de la sociedad hispánica medieval, que es una sociedad de castas (de tres castas definidas según un criterio "cultural-religioso": cristianos, judíos y musulmanes) en una Monarquía Católica que consagra la unificación "religioso-racial" de "los españoles" asentándola sobre tres pilares complementarios: 1. La expulsión "religiosa" de judíos y musulmanes; 2. La persecución "religioso-racial" de los cristianos conversos de origen judío o musulmán —es decir, de los marranos y de los moriscos - que culmina, en el caso de estos últimos, con su expulsión; y 3. La escisión de la casta cristiana, convertida en casta única por la expulsión de las castas judía y musulmana, en dos subcastas jerarquizadas: los "cristianos viejos" o "castizos" y los "cristianos nuevos" o "maculados".

La ausencia en la península ibérica, durante la época medieval, de un todo socio-simbólico unitario al que referir, y en cuyo marco armonizar, las tres castas (cristiana, judía y musulmana) es una de las principales objeciones que cabe hacer a la presentación de las sociedades medievales hispánicas como sociedades de castas, al menos si deseamos - como es nuestro caso- conservar como modelo teórico de sociedad de castas a la sociedad india, estructurada, según el antropólogo Louis Dumont (1966), en base a los principios básicos de holismo y jerarquía, de los cuales deriva la complementariedad entre separación e interdependencia.

Al hacer esta objeción no pretendo apuntarme al purismo de los indianistas que ven con sospecha la aplicación de la categoría "casta" (que en sus textos equivale, dicho sea de paso, unas veces a varna y otras a jati) a otras sociedades fuera de la India, incurriendo en la paradoja de negarle su pertinencia para el análisis del ámbito lingüístico y cultural en que surgió, sino señalar la posible fecundidad de una comparación sistemática entre la sociedad india de castas — tal y como aparece a la luz del análisis estructuralista de Dumont - y las sociedades de castas de la península ibérica medieval.

Obviamente, proceder a esa comparación está fuera de mis posibilidades. Sólo quiero llamar aquí la atención sobre un punto que me parece de interés: en los dos casos — la India y la España medieval- lo que define a las castas es un principio religioso de pureza, pero en el caso indio ese principio es el mismo para todas las castas, que comparten un mismo marco politeísta de creencias, valores y ritos basado en los Vedas y elaborado por

lo que el fundamento empírico de la interpretación que propongo (que es una interpretación de la interpretación de Stallaert) es, exclusivamente, el recogido en los libros de esta autora. 
el brahmanismo primero y por el hinduismo después, mientras que en el caso "español" cada una de las castas tiene su propio y específico principio de pureza, que remite a su propio marco monoteísta de creencias, valores y ritos.

Cabría quizá sugerir, no obstante, que el monoteísmo semítico común —el hecho de que las tres religiones sean "Religiones del Libro", surgidas sucesivamente de un mismo tronco profético mosaico- constituye ese principio común que echamos en falta. En cualquier caso, lo cierto es que, a diferencia de lo que ocurría en los Estados musulmanes, las sociedades de castas de los Reinos Cristianos hispánicos medievales obedecían a un fundamento teológico de carácter sincrético, pues el cristianismo predominante estaba doctrinalmente tamizado en aspectos sustanciales por el islam y por el judaísmo. Para empezar, el modelo teológico de convivencia entre las tres "castas" en los Reinos Cristianos era un modelo islámico:

Era, en cierta forma, una copia del modelo social vigente en al-Andalus con la sola diferencia de un trasvase del poder a favor de la casta cristiana [...]. El prolongado contacto con el islam había convertido a la España cristiana en una excepción dentro del mundo cristiano. La base ideológica del sistema de convivencia fue la aceptación por parte de los cristianos del principio coránico de la tolerancia respecto de "las gentes del Libro" y de un concepto ecuménico de la Providencia. Hay que señalar, no obstante, que tal principio era ajeno a la doctrina cristiana de la época, lo que explica que esta estructura social tuviera una base más firme en la sociedad musulmana que en la cristiana [...]. La erosión progresiva de la sociedad de convivencia a partir de fines del siglo XIV se debe en gran parte a esta falta de base doctrinal, y a medida que fue creciendo el problema de los conversos, fue desapareciendo también el concepto ecuménico de la Providencia (Stallaert 1998: 24) [énfasis mío].

En segundo lugar, si el modelo general era islámico, el criterio de adscripción a las castas provenía del judaísmo:

La identidad social del individuo estaba determinada por el nacimiento dentro de la casta judía, musulmana o cristiana. Cada casta religiosa formaba una comunidad cerrada, que en principio no permitía cambios individuales de una casta a otra (Stallaert ibid.: 25).

La impermeabilidad de las fronteras intercastizas estaba garantizada por la prohibición de la apostasía ${ }^{2}$ y por la prohibición del proselitismo ${ }^{3}$.

2 "En las Siete Partidas, la conversión de cristianos al islam o al judaísmo se castigaba con la pena de muerte. El legislador cristiano prohibía, además, las conversiones de judíos al islam o de musulmanes al judaísmo [...]. También las castas judía y musulmana reprimían severamente la apostasía de sus miembros" (Stallaert $i b i d$.).

3 "Las Partidas prohibían el proselitismo judío y musulmán [...]. Si bien las conversiones al cristianismo no eran proscritas, [...] en la práctica no se desarrolló ninguna políti- 
En la sociedad de castas de la España medieval, se nacía y se permanecía cristiano, musulmán o judio: era el nacimiento lo que determinaba para siempre la adscripción "religiosa", convertida de este modo en una esencia inmutable genealógicamente transmisible. Lo cual no era una novedad para los judíos, pero sí para los musulmanes y para los cristianos, que pasaron de este modo a asumir como propio el criterio judío de etnicidad.

Tanto el cristianismo como el islam han sido, desde su nacimiento hasta hoy, religiones misioneras entregadas a un intenso proselitismo. También el judaísmo en un principio - $-\mathrm{y}$ especialmente durante los siglos anteriores y posteriores al cambio de era- buscó las conversiones y, en virtud de ellas, creció espectacularmente en el Imperio Romano. Pero la dura competencia del cristianismo en expansión primero —reclutando sus prosélitos en las sinagogas - y el cierre voluntario de las comunidades judías ante la creciente hostilidad cristiana después, llevaron al judaísmo rabínico a renunciar prácticamente al proselitismo, a hacer cada vez más difíciles e improbables las conversiones y a descansar sobre un criterio de identidad religiosa y social ("es judío el nacido de madre judía") que hace, de facto, del judaísmo una religión que se transmite por vía genealógica ("biológica"): una religión que se hereda por vía materna, una "religión racial" que sacraliza ritualmente una diferenciación étnica. La extensión a los cristianos y a los musulmanes de este nuevo criterio de adscripción supone una efectiva judaización del cristianismo y del islam hispánicos, que pasan a ser, de este modo, marcadores simbólicos, religiosos, de unas "castas" que pueden, eventualmente — con sólo enfatizar el carácter biológico de la transmisión de la religión-, transformarse ideológicamente en "razas".

Para entender la dinámica profunda del proceso histórico posterior es preciso no perder de vista que el requisito de perduración del sistema de convivencia de las tres castas es un principio de adscripción basado en el nacimiento, que hace del cristianismo, el islam y el judaísmo religiones que se transmiten por vía biológica. Tampoco hay que perder de vista que, correlativamente, el principal enemigo de tal sistema de convivencia es la conversión, el traspaso de las fronteras intercastizas. Conversión religiosa que, a la luz del criterio de identidad de casta basado en el nacimiento, no puede dejar de ser vista más que como muy improbable, casi tan imposible como una transformación biológica: cambiar de "religión" equivalía a cambiar de "raza".

ca oficial de proselitismo cristiano [...]. La conversión al cristianismo, aunque oficialmente permitida, era socialmente condenada. Teniendo en cuenta este rechazo social, las Partidas intentaban proteger al converso contra las vejaciones sociales" (Stallaert ibid: 25-26). 
Además del holismo -inexistente en el hispánico- los rasgos definitorios del sistema de castas indio son la jerarquía, la separación entre las castas y la interdependencia de cada una respecto de las demás. La jerarquía, entendida en la India como jerarquía de valor (que permite la subordinación axiológica del poder de los kshatriyas a los brabmanes y el reconocimiento por las castas más bajas de la superioridad de las más altas), comparece en los Reinos Cristianos medievales de forma pervertida, degradada, como simple desigualdad de poder, al no existir en ellos un marco de valores común: la casta cristiana tiene la supremacía porque detenta el poder político-militar y la judía y la musulmana, vinculadas directamente a la persona del Rey, están políticamente subordinadas de facto a la cristiana, aunque estén muy lejos de reconocer su superioridad axiológica. La supremacía cristiana quedaba patente también en la jurisdicción, especialmente en la penal y en los "pleitos mixtos", siendo más igualitaria en las causas civiles juzgadas por tribunales de la misma casta del acusado.

La famosa tolerancia entre las tres - manifiesta en el supuesto respeto a la religión del otro y en la fidelidad a la propia Ley- debe ser vista, desde la perspectiva de la desigualdad de poder entre las castas, como la otra cara - la amable- de las normas de segregación que garantizan la impermeabilidad de las fronteras intercastizas. Precisamente porque la tolerancia está al servicio de la separación (al servicio, sobre todo, del mantenimiento de la pureza de la casta cristiana), su contrapartida es la intransigencia al interior de la propia casta: por los mismos motivos que toleraba la religión de judíos y musulmanes, la cristiana, obsesionada por una pureza que identificaba con la más estricta ortodoxia religiosa, extremó su celo ante sus propios herejes y heterodoxos, e invitó a hacer lo propio a musulmanes y judíos ${ }^{4}$. Para que la casta cristiana fuera pura y ortodoxa, era preciso que

\footnotetext{
4 "La Inquisición papal no existía en Castilla y la represión de la herejía estaba en manos de los tribunales civiles. La severa represión de la herejía por la casta cristiana no era incompatible con la tolerancia de otras religiones. Al contrario, la casta cristiana velaba por la ortodoxia de musulmanes y judíos. El legislador cristiano procedía contra los judíos que exhibían un comportamiento poco ortodoxo, que no respetaban el sábado o que estaban en posesión de libros contrarios a la ortodoxia judía. Aparte de las disposiciones cristianas, cada casta disponía, a su vez, de instituciones que garantizaban la ortodoxia religiosa" (Stallaert 1998: 26). Sobre la intolerancia en el interior de la casta judía, tolerada y estimulada por la casta cristiana, escribe Israel Shahak: "En ningún otro país, con la excepción de Polonia, disfrutó la comunidad judía de tantos poderes legales sobre los judíos o los usó de forma tan amplia y pública, incluyendo el poder de infligir la pena capital. Desde el siglo XI la persecución de los Karaitas (una secta herética judía), azotándolos hasta la muerte si no se arrepentían, fue habitual en Castilla. A las mujeres judías que cohabitaban con gentiles, los rabinos les cortaban la nariz y explicaban que 'de esa manera perderá su belleza y su amante no-judío llegará a odiarla'.
} 
también lo fueran la judía y la musulmana: la impureza de éstas equivalía a la de aquélla, a la temida mezcla; y de la mezcla derivaba la herejía, atribuida con frecuencia al influjo de las otras religiones, especialmente de sus formas heréticas e impuras. Pureza doctrinal y de casta — religiosa y genealógica ("biológica") — eran concebidas como una misma cosa.

La separación entre las castas se aseguraba mediante una amplia normativa que prohibía el matrimonio y la relación sexual entre cristianos, judíos y musulmanes (asegurando así la endogamia de casta) ${ }^{5}$, no permitía la comensalidad en público y en privado, e impedía, dentro de los límites de lo posible, cualquier forma de contacto intercastizo, tanto directo como indirecto: estaba prohibida la cohabitación de miembros de castas distintas en una misma vivienda, la judía y la musulmana vivían en barrios propios (juderías y morerías) ${ }^{6}$, los cristianos no podían asistir a ritos y festejos de los otros ${ }^{7}$, los objetos o lugares sagrados estaban protegidos de la contaminación por severas disposiciones restrictivas ${ }^{8}$. Los baños públicos fueron ob-

A los judíos que tenían la osadía de atacar a un juez rabínico se les cortaban las manos. Los adúlteros eran encarcelados después de haber sido sometidos al escarnio público en el barrio judío. En las disputas religiosas, se cortaba la lengua de los que eran considerados heréticos [...]. Pedro I dio a los judíos de Castilla el derecho a establecer en todo el país una inquisición contra los judíos religiosos heréticos más de cien años antes del establecimiento de la más famosa Santa Inquisición Católica" (Shahak 1994: 60).

5 "En las Partidas, la endogamia se veía reforzada por la prohibición de todo contacto sexual con miembros de otras castas. El legislador cristiano estipulaba penas más severas para el judío que para el musulmán que incurriese en este delito [...]. Al mismo tiempo se preveían penas duras para la mujer cristiana que mantuviera contactos sexuales con judíos o musulmanes [...]. Los tribunales de las castas minoritarias intentaban también reprimir la exogamia. El tribunal judío condenaba a la mujer judía que mantenía contactos sexuales con no judíos [...]; el islam prohibía los contactos sexuales de mujeres musulmanas con hombres no islámicos..." (Stallaert ibid.: 26).

6 "Puertas y murallas las separaban del resto de la población. Este particular ordenamiento urbanístico no era necesariamente consecuencia de disposiciones legales, debiéndose más bien a una evolución espontánea [...]. Sólo a partir de 1412 y en el 'Ordenamiento sobre el ençerramiento', encontramos disposiciones legales que imponen la formación de ghettos" (Stallaert ibid.: 28).

7 "Mediante todo tipo de prohibiciones se intentó limitar al máximo las relaciones sociales de los cristianos con judíos o musulmanes. Quedaba prohibido a los cristianos tener conversaciones con los judíos, salvo en caso de necesidad, como los contactos del enfermo con su médico de casta judía. Las Partidas disponían 'la prohibición de trato frecuente y, sobre todo, de reuniones mixtas cristiano-judaicas en lugares y en actos de regocijo' [...]. A los cristianos se les prohibió la participación en bodas y entierros de judíos o musulmanes [...]. Criar niños de otras castas era considerado delito" (Stallaert ibid.: 26).

8 "A los no cristianos les estaba vedado el acceso a la iglesia durante el oficio. En los días festivos cristianos se solían tomar medidas complementarias a fin de evitar cual- 
jeto de una reglamentación estricta (asignándose a cada casta días de visita diferentes a fin de evitar todo contacto físico), se impidió el contacto indirecto a través de alimentos y medicinas ${ }^{9}$, y se reguló hasta la indumentaria y la apariencia física de las personas para evitar toda posible confusión ${ }^{10}$.

Es decir, las fronteras religiosas entre las castas se reforzaron con otras matrimoniales, sexuales, culinarias, residenciales, urbanas, vestimentarias y de hábitos cotidianos de todo tipo, hasta convertirse en fronteras étnicas casi infranqueables: como consecuencia, cada casta (equivalente a un grupo étnico generado por las normas de segregación) tenía, no sólo su propia religión, sino también su propia cultura en la más amplia acepción antropológica de la palabra; una cultura diferenciadora igualmente generada por la segregación: por la elección de determinados marcadores simbólicos dentro del patrimonio cultural tradicional, por el énfasis en los elementos diferenciadores y por la invención de otros muchos enteramente nuevos. Como revelará el difícil proceso posterior de conversión de judíos y musulmanes al cristianismo, cambiar de religión, bautizarse y cumplir los preceptos cristianos no bastaba para atravesar la frontera étnica y cambiar de casta. Ni siquiera un cambio completo y consumado de religión y de cultura, como el llevado a

quier contaminación judía. Las Partidas obligaban a los judíos a recluirse en sus casas el día de Viernes Santo. Otras disposiciones les prohibían salir a la calle durante toda la Semana Santa. Estas medidas eran motivadas por la acusación de ser los judíos los responsables de la muerte de Cristo. La inclinación deicida de los judíos se manifestaría con la crucifixión ritual de un cristiano preferentemente durante los festivos cristianos. Éstos estaban tan convencidos de estas prácticas judías que incluso las Partidas se hacían eco del delito de crucifixión ritual" (Stallaert ibid.: 27).

9 "A las mujeres, tanto a las cristianas como a las judías o musulmanas, que amamantasen a niños de otra casta se les aplicaba la excomunión [...]. Hubo restricciones severas en cuanto al consumo de carne o vino procedente de otra casta. A la prohibición del consumo de vino 'contaminado' se unía también la prohibición del cultivo de la vid en tierras pertenecientes a judíos o moros así como la de comercialización por parte de cristianos de vino producido por moros o judíos. A partir de finales del siglo XIV este tipo de medidas se fueron haciendo más severas. De esta época data la prohibición general sobre la venta de alimentos y administración de medicamentos a cristianos por musulmanes o judíos. Dado el cuasi-monopolio profesional de los judíos en el sector médico, al cristiano se le permitía consultar a un médico judío a condición de que el medicamento recetado fuera preparado por un cristiano" (Stallaert ibid.: 27).

10 "Las primeras medidas restrictivas en cuanto a la indumentaria de los judíos datan de 1258 [...]. También a los mudéjares se les impusieron medidas sobre su apariencia física, obligándoles a llevar el típico corte de pelo musulmán y prohibiéndoles seguir la moda cristiana. La situación empeoró a partir del siglo XIV. El Ordenamiento de 1412 no sólo contiene disposiciones sobre vestimenta, joyas y piedras preciosas o peinado, sino que impone a las castas minoritarias el porte de una insignia distintiva" (Stallaert ibid.: 28), 
cabo por muchos "marranos" perseguidos por la Inquisición, constituía a ojos cristianos una garantía de cambio: habría sido preciso cambiar de "sangre".

Es en el terreno de las funciones sociales, de las dedicaciones laborales o profesionales, en el que la separación entre las castas aparece más claramente como la otra cara de su interdependencia, al ser ambas el resultado de la división del trabajo entre las castas con arreglo a una distribución étnica. "La casta cristiana, fuertemente marcada por el largo proceso de Reconquista, se había erigido en casta militar" (Stallaert 1998: 29) y sus miembros se repartían entre caballeros, clérigos de diversa obediencia (a los obispos o a las órdenes religiosas) y campesinos relacionados de modo variable con la propiedad de la tierra, desde nobles terratenientes e hidalgos propietarios hasta labradores pecheros. La casta judía, ajena por completo al trabajo campesino y enraizada exclusivamente en el medio urbano, tenía "el monopolio en el sector financiero, el comercio, las tareas administrativas y en la medicina"11, mientras que la musulmana estaba formada por trabajadores manuales de los llamados oficios mecánicos, por artesanos y, en la región levantina, por horticultores al servicio de los terratenientes cristianos.

Esta división del trabajo se debía en parte al proceso de Reconquista y a las prescripciones peculiares de cada casta religiosa. Sánchez Albornoz [...] observa que el trabajo manual era simplemente incompatible con la condición hidalga, tan característica de la casta cristiana ${ }^{12}$. Tanto el islam como la religión cristiana prohibían ciertas prácticas financieras. El vacío profesional en el sector manual fue lógicamente colmado por la casta que, como consecuencia de la Reconquista, se había visto despojada de sus tareas administrativas, mientras que el sector financiero fue ocupado por la única casta que no se veía impedida por prescripciones religiosas. Al igual que en otros sectores de la vida social, el principio básico que regía la división laboral era la supremacía cristiana (Stallaert 1998: 30).

Esta supremacía axiológica de la casta cristiana — dentro de la cual se registraba, desde el punto de vista del poder y de la riqueza, una notable estratificación jerárquica, desde la alta nobleza al campesinado pobre pasando por una emergente burguesía urbana- se correspondía por lo general con un predominio político y económico de los cristianos sobre la casta musulmana, pero registraba una trascendental anomalía en la integración social de facto de la judía, cuyo estatus político y económico era, por una

\footnotetext{
11 "Dichas tareas se identificaban tanto con la casta judía que era muy difícil encontrar cristianos dispuestos a desempeñarlas. Incluso la Inquisición tendría que recurrir más tarde a médicos de linaje judío a falta de médicos cristianoviejos" (Stallaert ibid.: 29).

${ }^{12}$ Sólo los particulares hidalgos "vizcaínos" harán compatible su hidalguía — colectiva en Vizcaya y Guipúzcoa- con los trabajos manuales y los oficios serviles, dejando abundante huella en la literatura castellana de la sorpresa y el escándalo que ello provocaba fuera de su tierra.
} 
parte, inferior y dependiente del monarca, de la nobleza cristiana y del alto clero, pero al mismo tiempo, superior al de las capas bajas e incluso medias de la casta cristiana, cuyo descontento podía, por tanto, encontrar fácil canalización ideológica, religiosamente sancionada, en la judeofobia cristiana.

Desde el punto de vista ideológico, se trataba, en resumen, de una sociedad de tres castas edificada sobre un fundamento religioso cristiano con un par de importantes préstamos teológicos ajenos: uno islámico (la tolerancia respecto de "las gentes del Libro") y el otro judío (el criterio de adscripción y de identidad social determinado por el nacimiento).

Para que ese edificio social se sostuviera, era preciso reducir al mínimo la permeabilidad entre las fronteras étnicas, pues de ello dependía la preservación del valor supremo al que todo se subordinaba: la pureza y la ortodoxia de la casta cristiana, paradójicamente amenazada por ese cruce de fronteras que era la conversión. Digo "paradójicamente" porque era la pureza doctrinal cristiana la que impedía prohibir la conversión de judíos y musulmanes al cristianismo de modo análogo a como se prohibía la conversión de los cristianos al judaísmo o al islam; la casta cristiana pudo durante algún tiempo, por interés propio, renunciar de facto al proselitismo, pero nunca podría renunciar de iure a la esencia evangelizadora y misionera del cristianismo.

Ésa fue la grieta teológica del edificio social de las castas medievales por la que penetró el vendaval de conversiones que lo desmoronó. Dos tipos de presión se produjeron, desde finales del siglo XIV, sobre las fronteras étnicas de la sociedad medieval de castas: la presión de los judíos sobre su frontera con los cristianos, mediante la conversión masiva al cristianismo con que reaccionaron a la violencia judeofóbica, y la presión misionera y proselitista de los cristianos sobre su frontera con los musulmanes.

¿Qué es lo que provocó, en sus inicios, esa doble presión? Atribuir, como con frecuencia suele hacerse, la oleada de violencia antijudía -desencadenada en toda Castilla tras el pogrom de Sevilla en 1391- a la judeofobia teológica cristiana, es decir a un factor ideológico, supone olvidar que esa misma teología, centrada en la condena de los judíos como pueblo deicida, no había impedido hasta entonces la tolerancia e incluso el desvelo de la casta cristiana por la ortodoxia judía. Sobre la base de la perduración de un mismo antijudaísmo religioso, tuvieron que ser factores de otro género los que cambiaron para transformar esa actitud tolerante en otra agresiva, factores de índole social que tuvieron que ver, sin duda, con las funciones económicas desempeñadas por la casta judía y con su muy distinta relación — armónica en el primer caso, conflictiva en el segundo-con los sectores privilegiados o desfavorecidos de la casta cristiana (especial importancia tuvo su relación crecientemente hostil con el campesinado pobre y el bajo clero). 
En cualquier caso, la reacción judía a ese cambio de actitud de los sectores populares de la casta cristiana fue su conversión masiva al cristianismo, ya fuera por presión cristiana o por interesado deseo judío: el hecho es que numerosos judíos se hicieron bautizar y que, como resultado de esos bautismos, voluntarios o forzosos, en lugar de suprimirse sin más la frontera étnica entre la casta cristiana y la judía, se generó en medio de ambas una ambigua subcasta nueva, los judeoconversos o marranos, que "sacaban grandes provechos sociales de su nuevo estatus jurídico y social", pues "la nueva legislación antijudía no les afectaba y el bautizo les había abierto las puertas de la Iglesia y de la nobleza" (Stallaert 1998: 31).

Pero el bautismo y la simple conversión religiosa, con independencia de su mayor o menor grado de autenticidad, en modo alguno podía bastar para atravesar las múltiples barreras culturales que se habían ido levantando entre las castas judía y cristiana durante la larga época de segregación y tolerancia. Destruir esas barreras exigía mucho más que una política misionera de catequización y evangelización de los conversos de frágiles convicciones: exigía una política global de asimilación cultural de los nuevos cristianos que sólo podía producirse si rompían con el medio social en el que seguía vigente su cultura de casta judía.

De ahí que, para facilitar la integración de los judeoconversos, se intensificara en un primer momento la segregación de quienes seguían siendo judíos, hasta que la ineficacia de las medidas asimilacionistas, atribuida a la dificultad de romper la relación de los conversos con su casta de origen, condujo a la adopción de la medida más drástica: la expulsión de todos los judios no bautizados, destinada - como explica textualmente el Edicto de 1492- a facilitar la integración de los judios bautizados, de los conversos.

Esta misma secuencia histórica — conversión, asimilación frustrada, expulsión destinada a facilitar la integración - se repitió después, entre 1501 y 1525, con la población musulmana, aunque en este caso no hubo nunca impulso musulmán a la conversión, sino sólo respuesta forzada al proselitismo cristiano, lo cual explica quizá la diferente actitud posterior de marranos y moriscos ante la asimilación cristiana: colaboracionista la de los primeros (empeñados en borrar lo antes posible la antigua frontera étnica) y resistente la de los segundos, empeñados en mantener culturalmente su diferenciación étnica bajo la cristianización.

Pero antes de esa resistencia morisca, "la violación de los pactos de Granada, la política proselitista del cardenal Cisneros, las conversiones en masa de los mudéjares valencianos a raíz de las Germanías y la presión asimilista desembocaron en la expulsión de los mudéjares" (Stallaert ibid.) (énfasis mío), que fue el equivalente musulmán de la expulsión de los judíos de 1492. Ambas expulsiones tuvieron un carácter religioso: expulsio- 
nes de los no-bautizados, de todos aquellos que profesaban una religión diferente a la cristiana, fuera ésta la judía o la musulmana.

Un carácter muy diferente distingue a la posterior expulsión de los moriscos, en 1609, la cual rompió la simetría en el trato que la casta cristiana había dispensado a la judía y a la musulmana. Pues los moriscos expulsados se habían bautizado: eran cristianos de ascendencia musulmana, conversos al cristianismo de mayor o menor autenticidad, como conversos de origen judío eran los marranos. Tanto marranos como moriscos fueron escrutados, presionados, perseguidos, reprimidos por la Inquisición, pero sólo los moriscos fueron expulsados, y esta expulsión no puede ya ser considerada, como las anteriores de judíos y mudéjares, como una expulsión de gentes que profesaban una religión distinta de la cristiana, pues los moriscos, repito, eran cristianos, cristianos de dudosa convicción y autenticidad, cristianos que "islamizaban" — como los marranos "judaizaban"—, malos cristianos si se quiere, pero cristianos al fin y al cabo.

Las inútiles admoniciones y presiones del Papa y la Curia para impedir que un Monarca cristiano expulsara de un Reino cristiano a una parte notable de su población cristiana sin otro motivo que su ascendencia musulma$\mathrm{na}^{13}$ nos revelan las particularidades heterodoxas del singular catolicismo étnico definitorio de la identidad española, proclividades judaizantes que habían ido agravándose desde la introducción, en la segunda mitad del siglo Xv, de los primeros Estatutos de "limpieza de sangre", en abierto conflicto doctrinal con el Papa y la ortodoxia de Roma.

La expulsión de los cristianos moriscos es también reveladora de los cambios internos producidos en la casta cristiana entre 1492 y 1609. Expulsadas del país las castas judía y musulmana, con todos los súbditos de los Reinos Cristianos de España bautizados y convertidos al cristianismo, la cristiana se enfrenta a una situación en la que ha desaparecido la frontera religiosa entre los tres grupos étnicos pero permanecen las barreras culturales que los separan, cuidadosamente levantadas durante el período de convivencia para preservar la pureza de la casta cristiana.

13 "Cuando se preparaba la expulsión de los moriscos en 1609, los obispos enviaron informes sobre su perfecta asimilación religiosa, su ortodoxia y su praxis cristiana e incluso acerca de su piedad sacramental, pero el rey no se mostró conforme con que ese conjunto de actitudes y prácticas definieran una personalidad cristiana y ofreció a los obispos una regla práctica y un buen baremo mínimo de prueba de cristiandad: 'que ser notoriamente buenos cristianos se pruebe por actos positivos contra la secta de los moros y que ayan usado de vino y tocino y desviádose del algaravía y de los de su nación pues no vasta lo que prueban de que frequentan los sacramentos porquesto puede ser lo agan por su conservación, yncurriendo con ello en su mayor apostasía" (José Jiménez Lozano en Stallaert 2006: 224). 
La respuesta cristiana a esta situación nueva es doble y, en apariencia, contradictoria: por una parte, promueve una política asimilacionista de los conversos que considera imprescindible, para lograr su plena cristianización, suprimir las diferencias culturales generadas por la segregación anterior; pero, por otra parte, reacciona a lo que dice desear — la creciente asimilación cultural de los conversos, especialmente de los marranos- levantando una nueva frontera étnica que genera dos subcastas cristianas: los cristianos viejos, puros o "castizos" - por ascendencia o linaje- y los cristianos nuevos, impuros o "maculados", de ascendencia judía o musulmana.

Esa diferencia de "linaje religioso", basada en la religión de los antepasados, se categoriza sin embargo, paradójicamente, en términos "raciales", en términos de diferencia de sangre: lo que los cristianos viejos alegan defender contra los conversos es, ciertamente, su pureza religiosa, su ortodoxia cristiana; pero, en la medida en que conciben esa pureza religiosa como indisolublemente ligada a su limpieza de sangre, su supuesta ortodoxia cristiana se tiñe de rasgos heterodoxos, judaizantes, que le llevan al enfrentamiento doctrinal con Roma. "A fin de preservar la supremacía y la limpieza étnica cristiana — señala Stallaert (1998: 32-33) — se erigen dos instituciones, el Tribunal de la Santa Inquisición y los estatutos de limpieza de sangre", que "existían ya a escala reducida en el siglo XV o incluso en los siglos XIII y XIV para algunas cofradías militares" y que fueron generalizándose hasta que "en la segunda mitad del siglo XVI, los estatutos de limpieza se habían convertido en condición indispensable para tener acceso a un cargo público, militar o eclesiástico".

La diferencia discriminatoria que hacían los Estatutos entre cristianos viejos y conversos contradecía uno de los principios fundamentales del cristianismo, a saber, su universalismo, la abolición de las fronteras étnicas en el seno de la comunidad de creyentes. El papa Nicolás V reaccionó contra la Sentencia-Estatuto de 1449 con una bula en la que "so pena de excomunión, ordena que todos los convertidos, presentes o futuros, al cristianismo, sean descendientes de gentiles o de judíos, que viven como buenos cristianos, sean admitidos a todos los ministerios y dignidades, y a dar testimonio y ejercer todos los cargos con los mismos derechos que los cristianos viejos". A pesar de la inicialmente enérgica condena papal, el movimiento anticonverso fue extendiéndose a lo largo de todo el siglo XV, logrando finalmente romper la resistencia inicial de los poderes civiles y eclesiásticos contra este principio discriminatorio [...]. El recelo inicial de los soberanos españoles con respecto a los Estatutos fue vencido definitivamente por Felipe II, bajo cuyo reinado la limpieza de sangre sería reconocida oficialmente por la Iglesia y por el Estado españoles (Stallaert 2006: 249).

Lo más paradójico de esta heterodoxa defensa de la ortodoxia cristiana es que la etnización judeofóbica y antimora del catolicismo español que promueve, descansa en la asimilación de la concepción judía de la etnicidad. Así lo reconoce sin ambages el historiador judío-israelí Benzion Netanyahu 
(1999: 900): "resulta muy curioso que la idea del judeoconverso o cristianonuevo que prevaleció entre los cristianoviejos, o por lo menos entre los miembros del partido anticonverso, estuviera más cerca de la ley judía que de la idea apoyada por la Iglesia". El mismo autor lo explica:

La Iglesia mantiene que la conversión al cristianismo viene a sobreseer los componentes de esta unión, pues el judío, a su conversión, deja no sólo su fe, sino también su pueblo; pero no es esta la concepción de la ley judía. Distinguiendo entre la religión del judío y su pertenencia al pueblo judío la ley judía insiste en que el judeoconverso, aunque renuncia a su fe, sigue siendo miembro de su pueblo, con lo cual conserva también algunos de los derechos que esa posesión le confiere. Más aún, atribuye la misma asociación a su descendencia, con tal de que su madre sea de origen judío, aun cuando esos hijos ya no sean, como tampoco el padre mismo, religiosamente judíos (Netanyahu ibid.) (énfasis mío).

Aunque la categorización en términos "raciales" de la diferente ascendencia religiosa se aplique por igual a marranos y moriscos, la diferente actitud de unos y otros ante la asimilación cultural forzada por los cristianos introduce una significativa diferencia en el modo como éstos se distinguen de ambos. Los moriscos no sólo no ocultan su ascendencia musulmana, sino que se resisten a llevar su cristianización hasta la asimilación cultural completa y producen una contracultura étnica específica que será considerada criptoislámica por los cristianos y criptocristiana por los musulmanes africanos. La presión asimilista cristiana, tendente a derribar todas las barreras culturales levantadas por la anterior segregación de la casta musulmana (desde la residencia en "morerías" hasta la peculiaridad indumentaria y los cementerios separados) fue más débil que la presión de la comunidad morisca contra la integración: como resultado, la permanencia residencial en ghettos, el uso de la lengua propia (la algarabía) o, en su defecto, la valoración fetichista de los caracteres árabes, y las costumbres culinarias y alimenticias (especialmente, la evitación del cerdo y del vino), se convirtieron en signos externos, públicos y perceptibles, de la diferencia étnica morisca hasta su expulsión ${ }^{14}$.

Precisamente porque los moriscos se aferraban a esos signos externos distintivos, los cristianos viejos no tenían especial dificultad para percibir físicamente su diferencia, su incompleta o inauténtica cristianización, y puede decirse que su categorización en términos "raciales" — dejaban ver su "linaje musulmán”- - tenía al menos un fundamento taxonómico de carácter físi-

\footnotetext{
14 "Se calcula que unos 300.000 moriscos abandonaron el país. Sólo en casos excepcionales se les eximió del exilio. Un criterio a tener en cuenta era, entre otros, el hecho de comer cerdo y beber vino o el haber ingresado en una orden religiosa" (Stallaert 1998: 41).
} 
co, sensible, perceptible, aunque en modo alguno biológico ${ }^{15}$. No obstante, las "razas" no siempre se ven, y los prejuicios raciales más sólidos y persistentes se han dirigido con frecuencia a "razas" invisibles, imperceptibles, ocultas $^{16}$.

Eso es lo que ocurrió, en contraste con los moriscos, con la mayoría de los judeoconversos o marranos, decididos colaboradores de la política de asimilación que garantizaba la conservación de su estatus social y entusiastas enterradores de cualquier posible signo delator de su ascendencia judía, incluido el apellido. Precisamente porque la sistemática ocultación del origen judío de los marranos suprimió cualquier signo físico, externo, manifiesto, perceptible, de su ascendencia religiosa y de su consiguiente impureza de sangre, los cristianos viejos hubieron de recurrir, para demostrar su limpieza de sangre, que les distinguía de los conversos, a la prueba documental de su inmaculada genealogía. Y cuanto más dependiente de la genealogía se volvía la probanza de limpieza de sangre, más urgente se hacía el cambio de apellido para borrar el rastro judío y más proliferaba el lucrativo oficio de la falsificación genealógica, ilustrando de ese modo una ley que es, sin duda, la fuente principal de la pesadilla paranoica en que desemboca el racismo dirigido contra razas invisibles como los judíos: cuanta más importancia concede una sociedad a la genealogía, más invita a su falsificación, y menos posibilidades hay, por tanto, de que las relaciones genealógicas coincidan con las genéticas.

Los racistas modernos, científicos o pseudocientíficos, buscarán la esencia oculta de la raza en lo más interior y recóndito del individuo, en sus

15 La consideración de los moriscos como una raza - como una raza, obviamente, distinta de la "raza española" — ha tenido una larguísima perduración. Para Menéndez Pelayo, por ejemplo, "el conflicto morisco fue [...] en esencia una lucha de razas, lucha que se sella normalmente con la victoria de la raza superior y el exterminio o expulsión de la raza inferior. El odio que el cristiano viejo profesaba al morisco era una odio de razas [...]. La expulsión fue una medida saludable, cuyo único defecto fue no haber sido tomada antes" (Stallaert ibid:: 50). En el tomo XIX, libro I, pp. 41-58, de la Historia de España dirigida por Menéndez Pidal, "los moriscos son calificados de 'raza exótica', 'neoplasmas cancerosos en la carne española', 'aquella raza definitivamente irreductible', 'aquella raza inasimilable', 'aquellos incivilizados malhechores', 'gente feroz y salvaje', 'espinas envenenadas clavadas en la carne nacional”" (en Stallaert ibid.).

${ }^{16}$ El caso histórico más notorio es el de Hitler, que confiesa, en Mi lucha, su incapacidad para distinguir empíricamente a un judío de un no-judío dentro de la población vienesa, lo que no le impidió, mediante el estudio, llegar a la conclusión teórica de que los judíos eran una raza infecta y peligrosa que había que exterminar. Cuando se decidió a hacerlo, sólo pudo encontrar como criterio definitorio de pertenencia a la raza judía el registro documental de la genealogía. 
genes. Los cristianos viejos españoles creyeron encontrarla en aquello que su religión postulaba como más interior y recóndito: el alma.

El proto-racismo cristiano-viejo español tenía un fundamento doctrinal religioso, alegaba una justificación teológica de la diferencia "racial" con los conversos:

\begin{abstract}
Ni siquiera el bautismo era capaz de lavar la mancha que afectaba a los descendientes de judíos y musulmanes. La moralidad perversa de los judíos, que se había manifestado en el acto deicida, se transmitía de padres a hijos por vía de la sangre. El feto recibía desde el mismo momento de la concepción las inclinaciones morales de sus progenitores. Este determinismo biológico impedía cualquier eximición de la culpa [...]. Los moriscos eran declarados de sangre impura al ser los descendientes de la esclava Agar. Su ascendencia les convertía en un linaje bastardo, esclavo, indigno de gobernar o de desempeñar cargos importantes (Stallaert ibid.: 34-35).
\end{abstract}

Pero no me cansaré de insistir en que lo más paradójico de este racismo religioso judeofóbico de la casta cristiano-vieja en la España inquisitorial es que es bijo en línea directa de la judaización del cristianismo del periodo de convivencia entre castas, es decir, es bijo de la adopción del nacimiento como criterio de adscripción étnico-religiosa a las castas. Para el judaísmo rabínico, su religión, la pertenencia al pueblo elegido, se heredan por vía biológica (se nace judio y se permanece judío aunque se abandone la práctica religiosa); de modo similar, para las tres castas medievales, sus respectivas religiones se heredan por vía biológica: se nace cristiano, judío o musulmán. Para la subcasta cristiano-vieja sigue vigente el mismo criterio de adscripción religiosa en virtud del nacimiento: en los cristianos viejos o "castizos" se confunde la pureza religiosa, la ortodoxia cristiana y la limpieza de sangre; en los cristianos nuevos, sigue siendo el nacimiento, la sangre, lo que determina su condición religiosa. Desde el punto de vista "castizo" los conversos siguen siendo de sangre judía o musulmana y, por ello, de religión criptojudía o criptomusulmana, pero desde un punto de vista estrictamente religioso son cristianos, al menos en apariencia, puesto que han sido bautizados. El único modo de resolver la contradicción y de conciliar ambas perspectivas es decir que son necesariamente malos cristianos, cristianos falsos, cristianos impuros, porque su sangre es judía o musulmana y les fuerza a ser, ocultamente, judíos o musulmanes.

Cuando las castas estaban separadas y cada uno profesaba la religión que su sangre exigía (sangre que le transmitía la religión de sus padres) no había problema alguno y los cristianos toleraban la religión judía y la musulmana, e incluso favorecían la defensa intolerante de sus respectivas ortodoxias, pese a que pensaban, como seguirán haciéndolo los cristianos viejos, que el pueblo judío era un pueblo deicida y que los musulmanes 
descendían de la esclava Agar. En lo fundamental, no es la teología cristiana del judaísmo o del islam lo que cambia cuando la tolerancia da paso a la expulsión y a la persecución; el cambio radica en que, aunque sea por presión cristiana, judíos y musulmanes han dejado de ser fieles a su sangre, mezclando la religión que ésta naturalmente transmite, la de sus antepasados, con la religión cristiana a la que se han convertido; por eso el cristianismo de los conversos no puede ser más que impuro, como impuros son los propios conversos tanto desde la perspectiva de la casta cristiana como desde el punto de vista de sus castas de origen.

La sangre mora o judía que, en el sistema de castas, transmitía la religión musulmana o judía, la sigue transmitiendo igualmente ahora, pero, desde la perspectiva exclusivista cristiana de los "castizos" — que ha pasado de ser la casta predominante a ser la única-, la presencia de esa sangre y esa religión en los conversos equivale a impureza religiosa, a una mancha imborrable que se transmite ahora como tal a través de la sangre de los conversos.

El cristiano viejo es puro de religión (católico ortodoxo sin desviación herética alguna) y limpio de sangre ( $\sin$ mezcla de sangre mora o judía): ambas cosas van siempre juntas. Por eso, hay una especie de simetría invertida entre el converso, cuya impureza religiosa deriva de su impureza de sangre, y el hereje, el cristiano disidente, al que en virtud de su impureza religiosa se atribuye una impureza de sangre que se vuelve hereditaria. Para el cristiano viejo, tanto los conversos como los herejes son cristianos nuevos, impuros ambos así de religión como de sangre y condenados a transmitir esa doble impureza a sus descendientes. No es casual que los inquisidores atribuyan con frecuencia las herejías cristianas al influjo judío o musulmán, a una mezcla de religiones de la que derivaría la impurificación de la cristiana, de modo análogo a como la mezcla de sangre mora o judía mancha irremisiblemente la sangre cristiana.

De ahí que crea necesario matizar una de las tesis de Christiane Stallaert, para quien "la identificación étnica del español con la norma católica ortodoxa", producida bajo la hegemonía cristianovieja, supone un paso "del casticismo biológico al ideológico" (1998: 42-43). En mi opinión, el predominio del casticismo ideológico, de la obsesión ortodoxa por mantener la pureza del cristianismo contra los extranjeros (en donde se incluye una larga nómina que empieza con judíos, musulmanes, conversos y herejes, para prolongarse más tarde con protestantes, masones, liberales, comunistas y heterodoxos de cualquier género) no suprime en modo alguno el casticismo biológico obsesionado con la limpieza de sangre.

El nacional-catolicismo español judeofóbico y antimoro tiene la peculia- 
ridad "berética" "17, de origen paradójicamente judio, de concebir la religión cristiana no sólo como un marcador simbólico de la etnicidad española, sino también como un componente definitorio de la "raza española".

La etnicidad o proto-nacionalidad española nace, de facto, de un largo proceso histórico de limpieza étnica a mayor gloria del absolutismo católico, y para el nacionalismo español, finalmente, resultante ese desenlace se acaba formulando en un doble y complementario lenguaje, religioso y "racial": el español —se dirá- nace católico (como el judío nace judío), su cristianismo es un cristianismo biológico, un cristianismo que se lleva en la sangre y cuya pureza se mantiene sólo si se mantiene a la vez la limpieza de sangre. Pero un linaje cristiano de sangre limpia lleva camino de convertirse ideológicamente en una "raza", en una "raza genealógica" primero y en una "raza biológica" después: en una "raza católica" a la que debe llamarse, para marcar su radical diferencia con otros pueblos que se han hecho cristianos pero que no nacen cristianos $^{18}$, "raza española"19.

La obsesión cristianovieja con la limpieza de sangre, fuente de incontables falsificaciones genealógicas, buscaba por doquier indicios de pureza y de impureza. La profesión era uno de ellos (la medicina y los oficios mecá-

17 "Las múltiples tensiones entre el Estado español y el Vaticano a lo largo de la historia son reveladoras de la especificidad del cristianismo étnico español. La creación de la Inquisición española estuvo marcada por el conflicto con el Vaticano en torno a la distinción entre cristianos 'nuevos' y 'viejos', que era contraria a la doctrina católica [...]. La Santa Sede no veía con buenos ojos los estatutos de limpieza de sangre que a partir del siglo XVI empezaron a dominar la sociedad española. La ordenación de sacerdotes mestizos y mulatos en el Nuevo Mundo fue hasta el siglo xviII motivo de desacuerdo. Mientras que según el Vaticano toda persona bautizada podía tener acceso al sacerdocio, el colonizador español prefirió atenerse al criterio étnico de la ascendencia cristianovieja [...]. La orden de expulsión de los moriscos no gozó de la aprobación oficial del Papa a pesar de la presión ejercida por los españoles [...]. Tampoco cabe olvidar que dicha expulsión fue un hecho único en la historia del cristianismo ya que se trataba de la expulsión de una comunidad cristiana de territorio cristiano" (Stallaert ibid.: 11-12).

${ }^{18}$ Julián Marías formula así esa peculiaridad española dentro del mundo cristiano: "los demás países europeos eran cristianos, pero no consistían en ello" (en Stallaert ibid: 11, nota 9; énfasis de Marías). A su vez, el filósofo español Manuel García Morente escribe: "Ese vínculo que une el catolicismo con España es algo esencial y consustancial con la persona misma de la nación. No es posible quebrantarlo, sin quebrantar en igual medida la sustancia hispánica de España. Si fuera posible que España, alguna vez, dejase de ser católica, España habría dejado de ser España, y sobre el viejo solar de la Península vivirían otros hombres que ya no podrían, sin abuso, ser llamados españoles" (García Morente 1943: 115).

${ }^{19}$ La existencia de una "raza española" es un presupuesto implícito en todas las interpretaciones del conflicto morisco como conflicto racial: ¿cómo podrían ser los moriscos una "raza distinta" sin una "raza española" de la que se distinguirían? 
nicos eran dedicaciones típicamente conversas), pero quizá el indicio más seguro de limpieza era la región de origen. La escasa presencia de moros y judíos en algunas zonas y su pronta adopción de estatutos de limpieza de sangre, hizo que, con respecto a esas regiones denominadas "limpias", el criterio geográfico predominara en cierta forma sobre el de limpieza profesional, "siendo así que una persona procedente de una región reputada limpia podía dedicarse a un oficio 'converso' sin comprometer automáticamente su limpieza de sangre" (Stallaert ibid.: 36).

Dentro de la jerarquía regional de limpieza, los andaluces ocupaban el rango inferior y los "vizcaínos" el rango superior:

A fines del siglo XV, Guipúzcoa ya había cerrado sus puertas a los conversos. En 1511 se procedió a la expulsión de todos los conversos que se habían refugiado en territorio vizcaíno con el fin de escapar a las garras de la Inquisición. En Guipúzcoa y Vizcaya, la concesión del derecho de vecindad dependía directamente de la limpieza de sangre del solicitante. Gracias al riguroso control de fronteras, ambos países forales pudieron prácticamente prescindir de un tribunal que velara por la limpieza de la población. La actividad inquisitorial quedó, efectivamente, muy limitada en estas zonas [...] (Stallaert ibid.) (énfasis mío).

Los "vizcaínos" se esmeraron como nadie en el proceso de limpieza étnica que generó la nacionalidad española, y su legislación foral "racista" hizo casi superflua la actividad inquisitorial, hasta el punto de que "vizcaino' se convirtió en sinónimo de cristiano viejo", y "los propios judeoconversos, presumiendo de la pureza de su linaje judío que descendía en línea directa de Abraham, se llamaban a sí mismos "vizcaínos" (Stallaert ibid.).

Sin embargo, los "vizcaínos", en su remontarse genealógico hacia el pasado para demostrar su limpieza de sangre y su hidalguía, no se contentaban con llegar hasta Abraham, sino que iban aún más lejos, pues se consideraban todos ellos un único linaje, una sola "gran familia" descendiente de Túbal, hijo de Jafet y nieto de Noé, que fue el primer poblador de la Península y trajo consigo a Vasconia el euskera, el monoteísmo, los fueros y el fundamento de toda nobleza.

No llegaban ni mucho menos tan lejos las genealogías de los linajes cristianoviejos que, ya desde el siglo XIV y sobre todo en el XVI, alegaban una ascendencia goda como prueba de limpieza de sangre y de nobleza. La referencia a la monarquía hispano-goda permitía proyectar simbólicamente hacia el pasado y vivir como nostalgia el anhelo presente de unidad político-religiosa y pureza étnica, anterior a la contaminación de la casta cristiana por sangre musulmana:

Llama la atención que, aunque en cuanto a la limpieza de sangre la contaminación por sangre judía era por lo menos tan importante como la por sangre mu- 
sulmana (y el peligro real de contaminación en muchos casos mayor), la presencia judía en suelo peninsular no llegó a servir de punto de referencia para la demarcación cronológica entre la España étnicamente pura y la contaminada. Los mitos étnico-históricos españoles carecen de referencias a una España 'prejudaica'. En cambio, la invasión musulmana sí se constituyó en principal hito histórico de la etnicidad española (Stallaert ibid.: 58-59) (énfasis mío).

Cabe alegar una excepción: el tubalismo "vizcaíno", que tuvo sus defensores en la corte de los Reyes Católicos como paradigma originario y legitimación mítica de la monarquía unitaria, y que fue utilizado por la burguesía burocrática "vizcaína", apologista de los fueros y de la hidalguía colectiva, para sustituir en la administración de los Austrias a cristianos nuevos, supuestamente judeoconversos, acusados de "maculados".

A diferencia del goticismo cristiano-viejo, el tubalismo vizcaíno situaba la mítica Edad de Oro de pureza étnica y religiosa no sólo antes de la "invasión musulmana" y de la presencia judía, sino mucho antes incluso de la invasión goda y de la romanización. En tanto que cristianoviejos por antonomasia, los "vizcaínos" descendientes de Túbal eran los más españoles de los españoles, pero precisamente por eso, por pasarse de españoles al considerarse descendientes de los antiguos iberos e identificarse con los cántabros que resistieron a los romanos (lo cual suponía considerar advenedizos o, cuando menos, no tan genuinamente españoles, a los hispanoromanos y a los godos, además de a los judíos y a los moros), no dejaban de suscitar cierto recelo en el resto de cristianoviejos, con pretensiones genealógicas más modestas.

Resultaba además que, frente a los usos del goticismo en las probanzas de hidalguía de linajes particulares, el tubalismo se utilizaba para legitimar una atípica hidalguía colectiva, basada en la consideración de todos los "vizcaínos" como un único linaje asentado en una sola Casa-Solar, que tenía difícil acomodo en el derecho castellano y numerosos opositores en la Corte. De tal forma que, profundizando en su acendrada españolidad cristianovieja, los tubalistas "vizcaínos", apologistas del euskera, de la legislación foral y de la hidalguía colectiva, acabaron por ofrecer la elaboración mito-simbólica del primer criterio diferenciador de etnicidad de los "proto-vascos" dentro de la proto-nacionalidad española: una modalidad de nobleza colectiva que hacía compatible el disfrute de ciertos privilegios hidalgos con el desempeño de oficios serviles y conversos, y que exigía como requisito de mantenimiento un cierre racista de la comunidad "vizcaína" cristianovieja al asentamiento de cristianos nuevos. Como consecuencia, lo que en España era un criterio de jerarquización estamental en el interior de la sociedad cristiana (la posesión o ausencia de hidalguía) se convirtió en Vizcaya y Guipúzcoa en un criterio de diferenciación étnica y separación territorial que 
aparece como la primera forma histórica clara de etnicidad entre los pobladores del País Vasco. De modo similar a como "los españoles" nacen de un proceso de limpieza étnica, "los vascos" — que empiezan por ser "vizcaínos" archiespañoles - nacen de las normas racistas de la legislación foral.

La proto-nacionalidad española católico-castiza y la proto-etnicidad "vizcaína" conviven armónicamente como partes de un mismo tronco ideológico cristianoviejo hasta finales del siglo XIX: el carlismo será el último testimonio histórico de su larga armonía y la abolición foral con sus secuelas (industrialización y emigración), lo que llevará al nacional-catolicismo vasco a desgajarse del tronco nacional-católico español que culmina en la Cruzada de Franco, aunque ambos tengan inicialmente y durante largo tiempo unos mismos enemigos: los liberales y los socialistas, último avatar de una "anti-España" que será también una "anti-Euzkadi".

Frente a la "invasión maketa" que es, para Sabino Arana, la emigración española al País Vasco, los "vizcaínos" cristianoviejos, convertidos en nacionalistas vascos, reaccionarán como lo hicieron sus antepasados "españoles" ante judíos, musulmanes y conversos: propugnando una repetición de la expulsión de los moriscos y de la persecución inquisitorial de los marranos, unidos ahora, junto a los propios españoles, en la figura unitaria del maketo, frente a cuya impureza religiosa y degeneración racial se alza hoy la "raza vasca", consustancialmente católica e incontaminada de sangre mora o judía.

\section{RAZa VASCa y RELIGión Católica en SABino ARANa}

La concepción que Sabino Arana tiene de las relaciones entre raza vasca y religión católica, así como su interpretación de la legislación foral vizcaína, que impedía el asentamiento de "extranjeros" en tierra vasca — calificada por Caro Baroja como "anticipo de leyes raciales"- las expone con meridiana claridad en su polémica con el carlista Echave-Sustaeta y Pedroso a propósito de los Fueros vasco-navarros ${ }^{20}$. El objeto de la polémica son las leyes XIII y XIV del Título I del Fuero Nuevo de Vizcaya de 1526 (Zugaza 1976), en el que se proclama la hidalguía colectiva, la nobleza y la limpieza de sangre de todos los vizcaínos, y se impide morar y avecindarse a moros, judíos y conversos ${ }^{21}$.

\footnotetext{
${ }^{20}$ Me he ocupado extensamente de esta polémica en Milenarismo vasco (2000: 466470). Las citas de Sabino Arana proceden de "El Partido Carlista y los Fueros vasko-navarros", en sus Obras Completas (1965).

${ }^{21}$ Dicen así: "Que por quanto todos los dichos Vizcaynos son Hombres Hijos-Dalgo, y de Noble Linaje, é limpia Sangre, e tenían de sus Altezas Merced, y Provissión Real,
} 
Sabino Arana entiende que con estas leyes los vizcaínos intentaban "preservarse del contagio del pueblo español" por temor a que hubiera "entre sus antepasados algún moro o algún judío"22. Echave-Sustaeta, por su parte, piensa que el rechazo era de carácter religioso y no racial, pues lo que deseaban los vizcaínos era "evitar el roce con los no católicos"²3. La contraargumentación de Sabino Arana no tiene desperdicio. Empieza por recordarle a Echave que no todo el Fuero de Bizkaya está escrito y que, por tanto, para interpretar su letra hay que atender a su espíritu general, tras lo cual declara que, dado el "españolismo" del carlista,

tiene por fuerza que juzgar las leyes bizkainas con un criterio exótico y peregrino, y allí donde vea la palabra moros o judios, atribuirla al espíritu religioso, y no al de raza. Porque en efecto: mientras éste nunca informó ley alguna española, porque la raza española nunca fue raza, sino un producto informe de la mezcla de varias y diversas gentes, leyes bizkainas hay de carácter fundamental que están inspiradas en la natural repugnancia que sentian las familias bizkainas a enlazarse con las extrañas, por la conciencia más o menos clara que tuvieron de su raza primitiva y singularísima o, más probablemente, por otras causas que no

sobre, y en razón, que los nuevamente convertidos, de Judíos, e Moros, ni Descendientes, ni de su Linaje, no puedan vivir, ni morar en Vizcaya". Siguen $-\mathrm{y}$ se prolongan en la Ley XIV, o Provisión Real sobre los nuevamente convertidos - las medidas, informes y averiguaciones ("se averigüe ser de limpia sangre") destinados a evitar el asentamiento de conversos, pues "algunas de las personas de las nuevamente convertidas a nuestra Santa Fe Católica, de judíos y moros y linaje de ellos, por temor que tienen de la Inquisición e por ser essentos y decir ser Hijosdalgo, se han passado, y passan de estos mis Reynos, y Señoríos de Castilla, a vivir, y morar en algunas Ciudades, Villas y Lugares del dicho Condado, e Señorío de Vizcaya; e que si no se remediase se podían recrecer algunos daños e inconvenientes en mucho deservicio de Dios y mío"; se impide que los conversos se puedan avecindar y se ordena a los que ya lo estuvieren "y Linajes de ellos [...] se vayan y salgan fuera de los dichos Lugares, e sus Términos".

${ }^{22}$ Continúa Arana: "Para estar avecindado en Bizkaya y ser ciudadano bizkaino era preciso: o ser originario de raza, o ser extranjero que hubiese probado no haber entre sus ascendientes ninguno de casta de moros o judíos. Esta ley creyeron suficiente los bizkainos para preservarse del contagio del Pueblo Español (que era el extranjero con quien más rozaban), pues sabido es lo difícil que sería hallar un español que no tuviese entre sus antepasados algún moro o algún judío, ya que moros y judíos habían habitado durante muchos siglos en España y cruzádose con la población indígena, la cual, a su vez, era producto de varias y muy diversas razas que habían invadido dicha tierra".

${ }^{23}$ Escribe Echave: "Los bizkainos querían rechazar a los castellanos, no por ser maketos, sino por ser (los que lo fueran) judíos o moros. Querían, pues, evitar el roce con los no católicos, no con los castellanos por ser castellanos, como lo prueba el hecho de encontrar a cada momento gente de procedencia castellana ocupando cargos de representación popular en Bizcaya [...]. Los bizkainos no quisieron preservarse del pueblo español, como usted dice en su Hoja, sino de los moros y judíos con capa de cristianos". 
hay por qué apuntar. Y de aquí se sigue que, mientras las palabras moros y judíos que aparecen en la legislación de España siempre han de entenderse expresivas de profesión religiosa, su presencia en las leyes bizkainas, por el contrario, puede muy bien obedecer al espíritu de raza, y no al religioso (énfasis mío).

En su argumentación, Sabino se apoya en el primer considerando de la Ley XIII ("Por quanto todos los [...] Vizcaynos son Hombres Hijos-Dalgo, y de Noble Linaje, é Limpia Sangre") para preguntarse a continuación:

Ahora bien, ¿qué significa esa Hidalguía, esa Nobleza y esa Limpieza de Sangre (que todo viene a ser uno) en boca de bizkainos? Ni más ni menos que lo que hoy llamamos pureza de raza [...]. ¿Por qué entonces los bizkainos hablaron sólo de moros y judíos y no aludieron a las otras razas? Porque en el tiempo que hicieron la ley no tenían que temer otras inmigraciones ${ }^{24}$.

Hasta aquí, el racismo sabiniano no es más que una prolongación, una profundización, una exacerbación del racismo cristianoviejo español de fundamento religioso. El rechazo "católico-español" de musulmanes, judíos y conversos se prolonga en rechazo "católico-vasco" de los españoles: los vizcaínos rechazan a los españoles porque sospechan que pueden ser cristianos nuevos, conversos que se han mezclado con moros y judíos, que son sus descendientes y que son, en cuanto tales, portadores de irreligión e inmoralidad. Esta línea de argumentación, que vuelve el racismo español contra los propios españoles y que convierte el anti-maketismo vasco en directa derivación del proto-racismo cristianoviejo español (tanto judeofóbico como antimusulmán y antiárabe), alegando una motivación fundamentalmente religiosa (el contacto maketo como fuente de pecado y de degradación moral y religiosa), es muy frecuente en Sabino Arana.

Pero también lo es otra que privilegia claramente lo racial sobre lo religioso:

${ }^{24}$ Y continúa: "Que para entender las leyes es preciso conocer el carácter de la época en que se escriben. Cuando los bizkainos la escribieron (en 1526) vieron que era el único remedio contra la repetida inmigración de moros y judíos y judaizantes, que perseguidos en España por la Inquisición se pasaban a Bizkaya para naturalizarse en ella y así salvarse de la justicia española [...]. Ya para entonces, otro tanto se había extendido la secta en España, que estuvo a punto de hacerse totalmente judía dicha nación latina, y que si el pueblo español dio muchas veces contra las aljamas fue simplemente por espíritu de bandidaje y no religioso: las razas árabe y hebrea habíanse ya enlazado con la española e inoculándola el virus anticristiano, y judíos y judaizantes había numerosísimos en la nobleza española, y judíos y judaizantes hasta en el clero y en los mismos conventos [...]. De donde se deduce que sólo con esta ley, y aun cuando los bizkainos no tuviesen (que sí la tenían) otra no escrita y referente a la pureza de raza, se preservaban de hecho del contagio del pueblo español". 
que era ley de raza y no de religión lo demuestra la misma letra de la ley, porque no prohíbe la entrada en el territorio sólo a moros y judíos, sino a cualquiera de su linaje, fuese bisnieto, tataranieto o más remoto descendiente, y sin reparar en si permanecían o no en el error, o en si eran buenos o malos conversos ${ }^{25}$.

Y completa su argumentación alegando que esa ley no hacía sino reflejar la antiquísima costumbre de reservar el derecho de "ciudadanía" a los autóctonos, a los nacidos en tierra vizcaína:

Era ésta la de no ser bizkaino y no tener, por consiguiente, ni voz ni voto en ninguno de los asuntos de la verdadera Bizkaya, que eran las Anteiglesias, ninguno que no fuese originario.

Sabino Arana tiene toda la razón al alegar que la persecución inquisitorial y foral a los conversos y a sus descendientes - marranos o moriscos de primera, segunda, tercera o cuarta generación- supone la consideración de la "mancha religiosa" como algo hereditario, algo biológicamente transmitido, y por tanto la transformación de una discriminación religiosa en discriminación "racial".

Pero por esa vía sólo obtenemos la genealogía proto-racista (judeofóbica y antimora) de la figura del maketo, no la genealogía ideológica de su opuesto, "la raza vasca". Para entender la directa vinculación entre ésta y la condición vizcaína de "Hijo-Dalgo, de Noble Linaje é Limpia Sangre", es preciso que nos detengamos en los sucesivos eslabones de la elaboración "mitológica" que lleva desde Zaldibia a Sabino Arana pasando por Echabe y Larramendi.

\section{E. Hidalguía colectiva, Limpieza de SANGRE y "RAZA VASCA"}

El carácter diferencial del desenlace de la crisis bajo-medieval en el País Vasco con respecto a otras áreas de los Reinos cristianos peninsulares fue la conquista - para todos los vizcaínos y guipuzcoanos, y para los pobladores de algunas comarcas de Álava y Navarra - de la hidalguía colectiva plasmada en la legislación foral ${ }^{26}$.

${ }^{25}$ Y sigue Sabino: "Tan ley de raza era la bizkaina que nos ocupa, que no sólo estuvo vigente en el siglo XVI, sino que también se aplicó con todo rigor en el XVII, en el XVIII y aún en éste en que vivimos, es decir, cuando de España no podían ya venir ni moros ni judíos porque habían sido expulsados de su territorio. Ni en este mismo siglo ha podido obtener ningún español carta de naturaleza bizkaina, si antes no hubo demostrado no contar entre sus ascendientes ninguno de casta de moros o judíos".

${ }^{26}$ Trato con detalle los distintos aspectos de ese importante proceso histórico en varios capítulos de Milenarismo vasco (Segunda Parte, I, 2, pp. 163-183, y Tercera Parte, Capí- 
Básicamente, ello supuso la extensión a la "tierra llana" - la generalización a la totalidad de los pobladores de Vizcaya y Guipúzcoa- de ciertos privilegios "burgueses" (la prohibición de ser sometido a tortura; la exención de determinados impuestos reales, de pagar pechas serviles y de ser llamado a levas militares) concedidos por el Rey a los habitantes de las villas que le habían ayudado a domeñar a la levantisca nobleza. Lo que esa conquista tuvo en el País Vasco de "tácita sentencia arbitral" entre los intereses de las distintas clases sociales explica que la legislación foral sancionara también, al mismo tiempo, la política nobiliaria de defensa del mayorazgo y el derecho de familia correspondiente, caracterizado por la obligación de mantener indiviso el patrimonio familiar, la libertad paterna para elegir heredero entre los distintos hijos y la transmisión del patrimonio indiviso propter nuptias del matrimonio heredero.

Aunque tanto los Fueros como los privilegios "hidalgos" que sancionaban constituían una clarísima novedad jurídico-política en relación con la situación social anterior, y aunque (como el resto de los fueros de otras villas y comarcas de los Reinos cristianos peninsulares que, en algunos casos, sirvieron a los vascos de modelo) no podían revestir otra forma - dado el orden socio-político de la época- que la de concesiones legales de los Monarcas a sus súbditos, la apología y defensa de los mismos frente a sus críticos en la Corte, y más adelante frente a los intentos "centralistas" por suprimirlos, recurrió a una estrategia retórica centrada en la inversión mitológica del proceso histórico efectivo: los Fueros se presentaron como una simple recopilación escrita de unos "usos y costumbres" cuyo origen se perdía en la noche de los tiempos, y la hidalguía colectiva, como el reconocimiento legal de la ancestral nobleza universal de vizcaínos y guipuzcoanos.

La legitimación legendaria de esa tradición inventada generó, entre los siglos XVI y XIX, una prolija "mitología" cuyos distintos ciclos temáticos se exigían mutuamente y se reforzaban ideológicamente entre sí. La nobleza universal de los vizcaínos (término general con el que pronto empezó a designarse a los pobladores tanto de Vizcaya como de Guipúzcoa) alegó como su origen y fundamento el desembarco en tierra vasca del patriarca bíblico Túbal, hijo de Jafet y nieto de Noé, primer poblador de la península ibérica y de quien "procede toda nobleza" (tanto la de todos los "vizcaínos" como la del Rey de España, cuyo derecho al trono se legitima en

tulo 1, 2, C, a: "La hidalguía colectiva: historia y plasmación foral", pp. 440-449). A la bibliografía allí utilizada y citada, hay que añadir un análisis reciente que confirma las líneas generales y las conclusiones allí obtenidas: el magnífico trabajo de José María Portillo Valdés, "República de hidalgos. Dimensión política de la hidalguía universal entre Vizcaya y Guipúzcoa” (1998). 
virtud de esa descendencia de Túbal, primer monarca de España). Remontándose a Túbal, esa nobleza originaria se vio pronto bendecida por la tempranísima cristianización de los "vizcaínos", quienes, nobles y cristianos todos desde la primitiva población de la tierra vasca y española, se habrían mantenido limpios e incontaminados de todo contacto con los invasores posteriores: celtas, romanos, godos, árabes, y —sobre todo- moros y judios.

Para la "mitología" vasco-iberista, que Humboldt hizo suya y difundió entre los románticos europeos, los vascos son los descendientes de los antiguos iberos (de los pobladores originarios de la Península) y el euskera la lengua que éstos hablaban. Para la complementaria "mitología" vascocantabrista, que tuvo también su prolongación científica ${ }^{27}$, fueron los vascos los protagonistas de lo que las fuentes históricas recogen como resistencia cántabra frente a la penetración romana (las "guerras cántabras"), resistencia que les permitió mantenerse libres de toda mezcla con los invasores. Como limpios y puros de toda mezcla con godos, árabes, moros y judios, se mantuvieron asimismo los vizcaínos en siglos posteriores, conservando incólume, como consecuencia, la limpieza de sangre y la condición de cristianos viejos.

Al reivindicarse como cristianos viejos, limpios de sangre mora o judía, hidalgos y nobles todos, los "vizcaínos" convirtieron en criterio de discriminación étnica (que por primera vez suministró una autoconsciencia colectiva diferencial a un grupo social - los futuros "vascos" - constituyéndolo como un grupo étnico) lo que, en el ámbito más amplio de la Monarquía Española de los Reyes Católicos y de sus herederos, funcionaba como un criterio estamental de jerarquización social: la posesión o ausencia de nobleza, que distinguía y separaba a los grupos sociales en el interior de España, constituyó para los "vizcaínos", hidalgos todos, un criterio de distinción y separación con el exterior, una frontera étnico-territorial sancionada por la legislación foral.

Y el núcleo central de la "mitología” que legitimó esa etnogénesis fue el mito de la continuidad física, biológica, genealógica, en una misma tierra, de una misma población, de un mismo pueblo, con la misma lengua, la misma religión, la misma cultura, los mismos "usos y costumbres" y las mismas "leyes viejas" (recogidas en los fueros), desde los orígenes hasta hoy.

En ese marco "mitológico" tiene lugar la elaboración ideológica que desemboca en el concepto sabiniano de raza vasca. Y esa elaboración empieza bien pronto, tanto en Vizcaya como en Guipúzcoa.

${ }^{27}$ Entre otros textos, en Los pueblos del norte de Julio Caro Baroja (1977), donde aplica al área vasco-cantábrica la teoría de los ciclos culturales de la Escuela Histórica de Viena. 
En Vizcaya, entre el Fuero Viejo (1452), que "suponía la existencia de diversos órdenes de vizcaínos (labradores e hidalgos) y mantenía una relación señorial de dominio compartido del territorio" (Portillo Valdés 1998: 427), y el Fuero Nuevo (1526) —-sobre cuya interpretación hemos visto discutir a Sabino Arana y al carlista Echave Sustateta- se produce una "significativa invención, la de una comunidad de bidalgos [...] dueños patrimoniales tanto del territorio como del conjunto de privilegios y libertades que el propio Fuero contenía", invención ésta de la hidalguía colectiva de la que "se deducía que era la propia tierra de Vizcaya la que atribuía tal estado, no la probanza personal de la misma según los requerimientos del Derecho" (Portillo Valdés ibid:: 428-429).

Fue el licenciado Andrés de Poza (1997) el primero que, en polémica con el fiscal de Valladolid, Juan García, elaboró la doctrina justificatoria de la reciente invención, basada

en una peculiar interpretación del solar como referente de la bidalguía y del infanzón como sujeto patrimonial del mismo [...]. El solar a que hacía referencia la idea de universalidad de la hidalguía vizcaína era, precisamente, la tierra de Vizcaya, toda ella. Vizcaya, más que el Señorío, constituía un solar capaz de ser reputado como continente de hidalgos, porque constituía una referencia común de linaje para todos los vizcaínos originarios [...]. En esa referencia de linaje común, y no propiamente en una aséptica tierra, estaba la referencia esencial; lo esencial era la calidad que la tierra, como solar toda ella, era capaz de transmitir como cualidad (Portillo Valdés ibid:: 429-430) (énfasis mío).

La argumentación "jurídica" de Poza exigía apoyarse en "historias", elaborar "mitos":

Que Vizcaya fuera solar de infanzones significaba que toda la tierra de Vizcaya podía asignar status, ser fuente indudable del mismo corporativamente disfrutado por los hidalgos infanzones vizcaínos. La cuestión principal estaba por tanto en mostrar que Vizcaya constituyera solar, que tuviera cualidades que dejaran fuera de duda esta capacidad del territorio mismo. Es ahí donde encajaban perfectamente unas historias, medio perfectamente probatorio en la cultura moderna y que Poza contribuyó como nadie a forjar. La suposición de un poblamiento original, la desconexión de dependencia respecto a imperios y dominios extraños, especialmente por su relevancia cultural el romano, capacidad para confederarse con formas políticas complejas como ese mismo imperio o la monarquía gótica, eran todas historias que demostraban (en el más literal de los sentidos jurídicos) que Vizcaya era solar. Pero sobre todo lo hacía el hecho de que esa misma tierra hubiera constituido, tras la "pérdida de España", un reducto desde el que se procediera a su recuperación y salvación. La tierra vizcaína podía reputarse por solar conocido por la sencilla razón de que era el solar, es decir, el lugar desde el que España había renacido. Vizcaya era solar conocido porque era la vagina de la que había nacido España. Este argumento conllevaba también una necesaria suposición: Vizcaya era una república [espacio de convivencia ciudadana] [...] 
adherida a la monarquía bajo el mantenimiento de una constitución propia que se sustanciaba en el Fuero, en el nuevo de 1526 que era condensación de su derecho y costumbre (Portillo Valdés ibid:: 430-432) (énfasis mío).

No creo necesario recalcar la larga perduración, a través de Sabino Arana y hasta el "soberanismo" del nacionalismo vasco en la actualidad, de la última parte de la argumentación de Poza. Pero no es eso lo que ahora nos interesa, sino la relación entre la concepción de Vizcaya como un solo solar de hidalgos y de los vizcaínos como un linaje común con el derecho de familia sancionado por el Fuero:

Esta república vizcaína se presentaba también como comunidad de hidalgos porque poseía en su derecho propio los mecanismos y previsiones pertinentes para asegurar en las familias hidalgas la transmisión del patrimonio doméstico, de la casa y tierra. El Fuero era al respecto la mejor evidencia al proteger en los matrimonios, ventas, permutas y herencias la raíz de esos patrimonios. Toda la raíz de Vizcaya (decía el Fuero en la Ley I del Tít. XX) es troncal, esto es, toda la tierra de Vizcaya estaba distribuida en una serie de troncos o familias a los que el derecho vizcaíno aseguraba la posesión de la raíz, de la tierra y casa [...]. Si la tierra toda de Vizcaya era solar conocido, útero de nobleza colectiva de sus gentes, los vizcaínos eran nación de familias, de troncos y raíces, de patrimonios domésticos perfectamente identificables por su permanencia. Eran las casas que nunca morían en Vizcaya (Portillo Valdés ibid:: 433).

Guipúzcoa no obtuvo hasta bastante más tarde que Vizcaya — hasta la Real Provisión de 1610 - un explícito reconocimiento de la hidalguía territorial por el Monarca, pero su imagen "legendaria" como república de bidalgos había empezado a elaborarse mucho tiempo antes, al menos desde los intentos iniciados en 1527 por fijar el derecho guipuzcoano. Un mojón importante en ese proceso ideológico lo puso el bachiller Juan Martínez de Zaldibia en 1564, con la publicación de su Suma de las cosas cantábricas y guipuzcoanas ${ }^{28}$. Tras narrar la llegada de Túbal a Vasconia, "la más antigua nación de España", introduciendo "la nobleza en el mundo", relata Zaldibia cómo han conservado los vizcaínos sus "leyes habidas en la ley de naturaleza" y su "lengua primera", el euskera, "grande argumento de no haber sido señoreada": en efecto, "dos veces vencieron a los romanos y quedaron libres de sujeción”, resistiéndose asimismo después a visigodos, suevos y alanos.

Convida mucho a esta gente - concluye Zaldibia-la estima que hacen de su limpieza y linajes, de que se precian hasta los rústicos y pastores; en especial se jactan mucho de haber siempre sido apartados de herejias, con judios, moros ni infieles nunca mezclados, y haber siempre guardado el puro nombre cristiano ${ }^{29}$ (énfasis mío).

${ }^{28}$ Cito por la edición de Fausto Arocena (San Sebastián, 1944).

${ }^{29}$ Y añade: "Y si algún judío por negocios fuere a aquella tierra, no le era lícito tardar en un lugar más de tres días y en toda la región más de trece, de donde se seguía 
De esta pureza de sangre deduce Zaldibia la nobleza vasca, y de la nobleza de "los de esta tierra" hace descender a "las familias nobles de los españoles y sus generosas prosapias y nacimiento", incluyendo a "los reyes de España". De ahí y de lo que alega como fundamento adicional de la bidalguía colectiva:

Pues, como estas Casas de fuera de las villas fueron edificadas por los hijosdalgo que fueron los primeros pobladores de la tierra y retienen sus apellidos antiguos sin que jamás hubiesen pechado, claro es que éstas son los solares conocidos antiguamente, y así los descendientes de ellas se llaman hijosdalgo de solar conocido e infanzones [...] porque en la Provincia todos son hijosdalgo y no hay tormento (énfasis mío).

La secuencia "mitológica" que establece Zaldibia ("hijosdalgo de solar conocido" edificando sus Casas, los "solares conocidos antiguamente", "fuera de las villas" y legando su hidalguía a sus descendientes que pueblan las villas) mixtifica e invierte el proceso histórico real tal y como está sobradamente documentado, por ejemplo en la villa de la que tanto el bachiller Zaldibia como su padre y su tío fueron alcaldes, Tolosa, la primera de las villas guipuzcoanas en obtener del Rey la exención universal de impuestos y pechas. En 1326, los tolosanos solicitaron y obtuvieron del Rey ese privilegio, reconociendo la diferencia entre quienes eran hidalgos y quienes no lo eran, y pidiendo la extensión a todos los villanos del privilegio de inmunidad "segunt que lo son fijosdalgo que agora moran". En 1374, en queja por no haber sido respetado dicho privilegio, insisten en lo mismo, pero ahora alegando "que la dicha villa es poblada toda de omes fijosdalgo et que son avidos por omes fijosdalgo por la corte del dicho rey nuestro padre". Lo que en 1326 era petición de ser tratados como hidalgos se convierte en 1374 en reivindicación de haber sido siempre hidalgos. Y lo que históricamente fue extensión a la tierra llana, durante la segunda mitad del siglo XIV y todo el XV, de la exención tributaria y de la hidalguía colectiva concedida a las villas, se convierte legendariamente en poblamiento de las villas por hidalgos nacidos en solares nobles "fuera de las villas" y "conocidos antiguamente". El mito neutraliza la historia y establece una continuidad entre el presente y los orígenes.

En Zaldibia nos encontramos ya definida la hidalguía colectiva o nobleza universal vasca como algo basado en la descendencia de Túbal, preservado mediante la limpieza de sangre (lo que Sabino Arana llamará "pureza de raza"), la fidelidad al cristianismo y la invencibilidad vasca, como algo

que, en oyendo los muchachos el nombre de judío, se espantaran no menos que si fuera de otra especie que la humana, y aún tienen privilegio para que ninguno de los nuevamente convertidos a nuestra santa fé católica pueda morar en aquella tierra". 
definido por el arraigo en una casa solar y patentizado en los apellidos que lo demuestran.

La fundamentación de la nobleza universal vasca en el doble pilar de la limpieza de sangre y la proveniencia de solar antiguo en tierra vasca equivale a convertir a todos los vizcaínos y guipuzcoanos en miembros de un solo linaje noble, de un único clan familiar, y al territorio de Vizcaya y Guipúzcoa en una sola Casa-Solar, noble y fuente de la nobleza de quienes en ella nacen.

Baltasar de Echave no duda en hacer explícitas estas conclusiones, y en sus Discursos de la Antigüedad de la Lengua Cántabra Bascongada (1607) dice, refiriéndose a los solares y casas de Guipúzcoa:

Aunque se an transferido unos en otros, mudandose unas familias en otras, no quita que siendo todos ellos unos, y parientes, sean unos mismos los que en los tales solares y casas subceden, aunque sea por vía de compra: porque como estas Prouincias sean muy limitadas en si, no an permitido mezclarse, en general ni particular con gente o nación estraña, ni no limpia e hidalga [...]. De que se sigue ser todos ellos deudos [...]. No tan solamente son estas casas y solares de notorios hijos dalgo de sangre, y solar conocido, si no que también, y sobre todo lo dicho, son estas Provincias un solar conocido y notorio de nobles hijos dalgo: y esto con tanta verdad que con solo prouar, ser naturales de padres y aguelos, de tiempo inmemorial, originarios de estas dos Provincias Vizcaya y Guipúzcoa, basta para sacar executoria [...] y los tengan por hijos dalgo de sangre, de solar conocido (Echave 1971: 66-67) (énfasis mío).

Lo que con toda esta construcción doctrinal se persigue es hacer sinónimos limpieza de sangre y nobleza de solar, identificando ambos con nacimiento en tierra vasca y con descendencia de Túbal: nacidos en un único Solar noble, todos los vascos son parientes, miembros de un único clan, de una sola "gran familia".

La más clara y coherente manifestación de esta consideración de Guipúzcoa (y lo mismo cabe decir, como hemos visto, de Vizcaya) como un único Solar noble, y de todos los guipuzcoanos - o vizcaínos- como pertenecientes a un solo Linaje, es la tesis de Guipúzcoa como gran mayorazgo histórico que defiende el Padre Larramendi, S.I. en sus Conferencias curiosas sobre los Fueros de Guipúzcoa ${ }^{30}$.

La historia guipuzcoana se inició cuando "Dios por su voluntad y dirección dividió el mayorazgo total de la tierra en otros mayorazgos menores que adjudicó expresamente a los hijos y nietos de Noé"; tras la confusión de lenguas, Túbal y sus hijos se convirtieron en "los ascendientes y primeros pobladores deste país y mayorazgo que hoi se llama Guipúzcoa”, esta-

\footnotetext{
${ }^{30}$ Citado por Fernández Albadalejo (1977).
} 
bleciéndose en él "sin obligación de pagar pechas, gabelas y tributos [...] con una nobleza de sangre tan pura y tersa que no la ha habido maior, y fue el principio de toda la nobleza de sangre española".

Además, el mayorazgo guipuzcoano ha sido el único en mantener estos bienes fundacionales e inalienables, conservando "intactos sus primeros mayorazgos, sus leyes y libertades", que no son otras que los Fueros.

En un claro antecedente de Sabino Arana, el jesuita vincula la idea de una nación vasca con derecho a la independencia a la idea de nobleza de sangre o "pureza de raza":

¿Qué razón hay, vuelvo a decir, para que esta nación privilegiada no sea nación aparte, nación por sí, nación entera e independiente de las demás? ¿Por qué tres provincias en España (y no hablo ya del reino de Navarra) han de estar dependientes de Castilla — Guipúzcoa, Alava y Navarra- y otras tres dependientes de Francia — Labort, Zuberoa y baja Navarra-? [...]. Todo guipuzcoano que viene de alguno de los solares de Guipúzcoa, siempre ha sido noble, siempre lo es y siempre lo será [...]. Esta nobleza de sangre les viene por herencia y suben con ella con la mayor limpieza del mundo hasta los primeros pobladores de España. No se la han dado los reyes, que la tienen de muy arriba y de más antiguo [...]. De ahí que no se admita por vecino de algún pueblo de Guipúzcoa al que no es hidalgo conocido [...]. No son admitidos para vecinos ni moradores, ni para residencia permanente, ni judíos, ni moros, ni los que tienen alguna raza de ellos, ni mulatos ni negros (énfasis mío).

Creo que se puede concluir que - por lo que se refiere a la "raza vasca"- lo que he propuesto llamar "concepto genealógico de raza" (es decir, la categorización de "los vascos" como grupo de parentesco, como "clan", como "gran familia" descendiente de un antepasado común) empieza a elaborarse con Zaldibia en el siglo XVI, madura con Echabe en el XVII y se consuma en el XVIII con Larramendi, quien además incorpora ya explícitamente a la construcción doctrinal sobre la nobleza de sangre de los vascos el término raza.

Es decir, la "raza vasca", concebida en términos sustancialmente idénticos a los que expone Sabino Arana, es un constructo ideológico plenamente elaborado desde al menos el siglo XVIII y cuyos fundamentos se sientan en el XVI. Y cumple además una importante función social como pilar central de una "mitología" muy difundida que legitima la hidalguía colectiva y la legislación foral.

\section{F. ¿POR QuÉ INVENTÓ SABINO ARANA EL NEOlOGismo "EuZKadi”?}

Los motivos que ofrece Sabino Arana para inventar literalmente el neologismo "Euzkadi" ilustran a la perfección cómo concibe la "raza vasca" y 
nos devuelven de paso al punto inicial de nuestra disertación: la "deuda judía".

Sabino explica con meridiana claridad ${ }^{31}$ el por qué de la invención de una denominación nueva, "Euzkadi", para designar a los vascos, así como el significado estricto que a esa palabra inventada quiso deliberadamente darle y la conexión necesaria de ese significado con el núcleo de su ideología.

El punto de partida de la reflexión lingüística, desbocadamente etimologista, de Sabino Arana es la oposición "ideológica y morfológica" que en el euskera se registra entre:

dos voces, dos nombres sustantivos: EUZKERA y ERDERA. La primera significa a la lengua nacional del vasko; y la segunda a toda lengua extranjera [...]. Los nombres euzkera y erdera tienen un elemento ideológico común: lengua. Tienen un elemento morfológico también común, que es en ambos terminal: era (énfasis mío).

Tras una larga especulación etimológica de la que deduce que "era significa lenguaje o palabra", Sabino concluye que "euzkera fue euzko-era, es decir, lengua de la gente vaska, lengua de la nación vaska, lengua del VASKO: lengua del EUSKO" y se interroga por la significación etimológica de erdera. Tras pasar revista a varias hipótesis considera que la más verosímil es la siguiente:

Er-(d)-era. De er por erri (gente, pueblo, nación) y d fonética: lengua de las gentes, lengua de las naciones. En efecto: también en latín, gens que significaba lo mismo que erri, sirvió para expresar nación precisamente extranjera [...]. El pueblo vasco, que a sí mismo se llamaba euzko, ¿no significaría con el sustantivo común de errijak (pueblos, naciones, gentes) a los extraños?

Tanto los vocablos latinos gens y natio, como sus derivados en lenguas romances (gentiles, naciones) traducen en las versiones latinas y romances de la Biblia el término hebreo goyim (en griego éthnē). En el Antiguo Testamento, Israel, el pueblo elegido, los judíos, se opone a los goyim; en el Nuevo Testamento, judíos y gentiles juntos forman el "pueblo cristiano", el "nuevo Israel", al que ahora se oponen los paganos o étnicos (tanto en castellano como en francés y en inglés, el significado inicial de los términos derivados del griego ethnikós es "pagano", no perteneciente al pueblo cristiano).

En significativa congruencia con estos usos lingüísticos, Sabino Arana añade tras el texto citado:

${ }^{31}$ Lo hace en el primer artículo del no1 de la revista Euzkadi (Bilbao, marzo de 1901) cuyo título es Euzko y que se abre con la siguiente "Advertencia: Encargado de escribir, como primer artículo para esta revista, la explicación de su nombre EUZKADI, formado hace años para denominar al pueblo vasko, me ha parecido bien partir del mismo origen con este trabajo sobre EUZKO" (Arana Goiri 1965: 1783). 
De ahí que San Jerónimo, elegantísimo imitador de los clásicos latinos, según Raimundo Miguel, llamaba gentes a los pueblos extranjeros con relación al hebreo, escogido por Dios para depositario de su Promesa y de sus Mandatos; de ahí que aun en español castellano, aunque no lo diga la Academia, hay un caso en que gentes significa naciones extrañas, con relación también a la judía, y es cuando de San Pablo se dice que fue el Apóstol de las gentes; y de ahí, por último, que el adjetivo latino gentilis (de una misma nación, nacional, consanguíneo) pasara, sustantivado y en plural, gentiles, a significar tanto como extranjeros, según el gramático y clásico latino Antonio, como gentes (pueblos, naciones) pasó a significar naciones extranjeras. Y bien mirado, aunque pueblo extranjero y nación, extraño y nacional, son términos de significados opuestos, nada tiene de particular que con naciones se designara precisamente a las extrañas y con nacionales a los individuos extranjeros. Cada pueblo tendría en su lengua, en efecto, un término propio para denominarse a sí mismo, y a los extraños los llamaría con el genérico e indefinido de pueblos, gentes, naciones. Esto, que aconteció hasta cierto grado en el latín, ¿no podría haber ocurrido en el euzkera? (1965: 1787) (énfasis mío).

Para Sabino Arana, la oposición lingüística entre euzkera y erdera remite a una oposición étnico-racial entre "nosotros", los euzkos o vaskos, y "los otros", erri-ak, los pueblos o naciones extranjeros: oposición que aparece a sus ojos como análoga a la que enfrenta a los judíos con los goyim o gentiles y a los cristianos con los paganos o "étnicos". Además, en su opinión, euzko procede de eguzko- $a$, que significa "el del sol"32, y fue el propio pueblo vasko el que se dio a sí mismo ese nombre que los romanos latinizaron convirtiéndolo en vascones ${ }^{33}$.

Sabino persigue obsesivamente "la presencia de euzko en otros nombres", tanto "dentro del actual territorio vasco" —-donde lo encuentra en "Vascones", en "Osquidates u Osquidetas", en "Morosgo", en "Menosca", en "Amezkoa", en "Orozko" y, lo que es especialmente importante para él, en "Gipuzkoa"

32 "Fue, pues, objeto de gran veneración entre los vaskos la rueda de cuatro rayos, símbolo del sol. Que a este astro le prestaran culto como a medio o como a término, como a obra de Dios o como a deidad, cuestión es ajena al presente escrito. Para nuestro objeto bástenos saber que los vaskos, sin duda desde los tiempos más remotos, veneraron al sol con culto tan extraordinario, que es, puede decirse, el único que, con el de la luna, han conservado hasta franquear las puertas de la historia. ¿Es pues inverosímil que este pueblo adorador del sol se llamara a sí mismo eguzko-a (el del sol)" (ibid.: 1795).

${ }^{33}$ En opinión de Sabino Arana, VASCO-nes es "Nombre con que los latinos conocieron a los vaskos del este y sur, que eran los más próximos a comarcas ya totalmente romanizadas, es decir, los que más relaciones guardaron con ellos y más conocidos, por lo mismo, les fueron. En una palabra: es el nombre nacional del vasko (euzko) latinizado, y aplicado por los romanos sólo a los vascos que más conocían. Su país se llamó Vasconia, con la terminación latina nia, que se encuentra en Hispania, Brittania, Sardinia y tantos otros nombres geográficos". 
(que vendría de $i$-(b)-euzko- $a$, "el euzko del agua") y en Bizkaya (que vendría de be-euzko-di-a, "euzkos de abajo")— como "junto al actual territorio vasco" y "lejos del actual territorio vasco", tras lo cual concluye:

De todo lo que queda visto, fácilmente se infiere que euzko no era nombre geográfico, de país, de territorio, sino nombre de sangre, de familia, de gente, de raza. Era euzko toda la raza vasca, y por tanto, euzko era cada tribu o porción suya, euzko cada familia de esta tribu, euzko cada individuo de esta familia. El euzkera no usa hoy el nombre euzko aisladamente. ¿Es acaso que posee otro étnico, de ulterior formación, para expresar pueblo vasko, gente, nación o raza vaska? No, ciertamente. He aquí un pueblo que, con ser singularísimo entre todos, carece de nombre. Y ¿qué mucho si no tiene personalidad? (énfasis mío).

Para Sabino Arana el necesario renacimiento del pueblo vasco, para el que él ha sido llamado por Dios, empieza por la adquisición de un nombre, de su propio y genuino nombre euskérico como pueblo. Ese nombre no puede ser Euzkelerria, pues ese nombre —escribe Sabino-

formado de euzkel y erri (pueblo), sólo puede significar pueblo del euzkera, sean o no vaskas las familias que lo compongan. Un barrio de gitanos euzkeldunes, tales como los hay en Nabarra y Gipuzkoa, es Euzkelerria; y, por el contrario, no lo son las grandes porciones de población vaska erdelduna que hay en Bizkaya, Alaba y Nabarra.

Si, como Sabino pretende haber demostrado, "euzko significó gente, familia o raza vaska" y debe por tanto pasar al léxico del euskera actual con el significado de "cada una de las porciones orgánicas que resultan de la primera división de la familia vaska, siendo así un euzko Laburdi, otro Nabarra, otro Gipuzkoa, otro Bizkaya, etc.", entonces

restaurado así el precioso nombre euzko con la significación que le es propia, fácil es ya formar un nombre euskérico adecuado para todo el Pueblo Vasko. Este no es más que un conjunto de familias vaskas (antiguamente estados separados): una agrupación localizada de euzkos. Ahora bien, para expresar la doble idea de conjunto y de localización hay un sufijo común a todos los dialectos y comarcas del euzkera: $d i[\ldots]$. Y, en conclusión, agregando el sufijo di al nombre euzko resulta el de euzko-di, significando etimológicamente conjunto de euzkos; y aplicando a éste la citada regla fonética, queda formado el nombre propio Euzkadi como el más natural, más castizo y más adecuado para significar al Pueblo Vasko en conjunto (énfasis mío).

En este texto justificatorio del neologismo Euzkadi, Sabino Arana deja meridianamente claro que su aspiración a la constitución de Euzkadi como nación política, como confederación de "Estados antiguamente separados" (Laburdi, Nabarra, Gipuzkoa, Bizkaya, etc.), no es sino la traducción política de una raza entendida como conjunto de euzkos, como "conjunto de 
familias vaskas" que "resultan de la primera división de la familia vaska" y reivindican por tanto proceder de un antepasado común. Es decir, el sujeto de la soberanía política en la nación vasca a la que aspira no lo concibe fundamentalmente Sabino Arana ni como un territorio con una determinada historia ${ }^{34}$ ni como los habitantes o pobladores de ese territorio con unas determinadas características lingüísticas y culturales ${ }^{35}$, sino como lo que los antropólogos llaman un grupo de descendencia (descent group), como un "conjunto de familias vaskas", que es exactamente lo que Sabino entiende por Euzkadi o "raza vaska".

De modo análogo a como, para los judíos, Israel era el conjunto de las doce "familias" o "tribus" formadas por los descendientes de los hijos de Jacob y se definía por su oposición a los goyim (las naciones de extranjeros, "gentiles"), para Sabino Arana Euzkadi era el conjunto de euzkos resultantes de la primera división de la familia vaska y establecidos en los siete Estados antiguamente separados (Bizkaya, Gipuzkoa, etc.) frente a un mar de errijak o naciones "paganas". Y de modo análogo a como Esdras y Nehemías establecieron una directa correlación entre el peligro de idolatría y la mezcla del pueblo judío con los goyim, así también Sabino Arana ofreció una justificación religiosa de la defensa de la pureza "racial" de los euzkos y de su necesidad de independencia política: "si en las montañas de Euskeria, antes morada de la libertad, hoy despojo del extranjero, ha resonado al fin en estos tiempos de esclavitud el grito de independencia, sólo por Dios ha resonado" (ibid.; énfasis mío). Y sólo porque estaba convencido de que "Bizkaya, dependiente de España, no puede dirigirse a Dios, no puede ser católica en la práctica" (ibid.), convirtió Sabino Arana a España en la más pérfida de las errijak "paganas" y a los españoles (los maketos) en el equivalente para los euzkos de lo que cananeos y amalekitas fueron para los antiguos israelitas y de lo que los goyim son para los judíos.

${ }^{34}$ En "La pureza de la raza" (Bizkaitarra n. 24, 1895) escribe Sabino: “¿es acaso la tierra que pisamos lo que constituye la patria?, ¿qué más nos da tener una Bizkaya libre aquí en estas montañas como tenerla en otra parte? [...]. Si se diera una Bizkaya, libre sí, pero constituida por la raza española, ¿sería en verdad Bizkaya?”.

35 En "Los invasores" (Bizkaitarra n. 4, 1893) había escrito Sabino: "Si fuera moralmente posible una Bizkaya foral y euskalduna (o con Euskera), pero con raza maketa, su realización sería la cosa más odiosa del mundo, la más rastrera aberración de un pueblo, la evolución política más inicua y la falsedad más estupenda de la historia [...]. Si nos dieran a elegir entre una Bizkaya poblada de maketos que sólo hablasen Euskera y una Bizkaya poblada de bizkainos que sólo hablasen el castellano, escogeríamos sin dubitar esta segunda, porque es preferible la sustancia bizkaina con accidentes exóticos, que pueden eliminarse y sustituirse por los naturales, a una sustancia exótica con propiedades bizkainas que nunca podrían cambiarla”. 
Tanto la independencia política como la pureza racial de los euzkos se hallaban subordinados, en el nacionalismo vasco de Sabino Arana, a la preservación de la fe cristiana: "entre ver a una Euzkadi libre, pero apartada de Cristo, y verla esclava, pero fiel a Cristo, el Partido Nacionalista Vasco optaría por lo segundo" (ibid.). Esta unión indisoluble entre el Dios cristiano en su versión católica y la raza vasca, entre Jaungoikoa ("el Señor de lo alto", Dios en euzkera) y el "conjunto de euzkos" que es Euzkadi, la generó y la hizo posible históricamente el segundo pilar del lema nacionalista $J E L$, es decir Legi zarra, las "leyes viejas", los Fueros que impedían el establecimiento en el País Vasco de moros, judíos y "cristianos nuevos" o conversos con sangre mora o judía. Para Sabino Arana, los Fueros eran las milenarias "leyes viejas" de los euzkos, algo equivalente a lo que el Talmud fue y sigue siendo para los judíos. Del mismo modo que el Talmud ha preservado y preserva la pureza religioso-racial de los judíos, los Fueros habían preservado la pureza religioso-racial de los euzkos, y su abolición por España había provocado la "invasión maketa" y la consiguiente degeneración moral, religiosa y racial: "La dominación española es en nuestra raza causa de profunda y extensa irreligiosidad, de extensa y dilatada inmoralidad" (ibid.).

Porque la alianza entre Euzkadi y Jaungoikoa es lo principal, puede Sabino añadir:

Nada importa [...] la extinción de nuestra lengua; nada, el olvido de nuestra historia; nada, la pérdida de nuestras propias y santas instituciones y la imposición de las extrañas y liberales; nada, esta misma esclavitud política de nuestra patria; nada, absolutamente nada, importa todo eso, en sí considerado, al lado del roce de nuestro pueblo con el español, que causa inmediata y necesariamente en nuestra raza ignorancia y extravío de inteligencia, debilidad y corrupción de corazón, apartamiento total, en una palabra, del fin de toda humana sociedad (ibid.).

En El Partido Carlista y los Fueros Vasko-Nabarros, obra en la que polemiza con el carlista Echave-Sustaeta acerca de la significación de las leyes forales que prohibían establecerse en tierra vasca a moros, judíos y conversos con sangre mora o judía ("cristianos nuevos", moriscos o marranos), Sabino Arana escribe con toda razón que si dichas leyes fueran sólo de carácter religioso y no también racial no tendrían por qué afectar a los "cristianos nuevos" por el hecho de que tengan entre sus cercanos o lejanos antepasados a personas de otra religión. Interpretando correctamente que la ideología casticista española de la "limpieza de sangre" de los "cristianos viejos" y la persecución inquisitorial de los conversos implicaban la conversión de la religión (cristiana, musulmana o judía) en un atributo natural que se transmitía a la descendencia por vía biológica (lo cual —añadimos noso- 
tros- equivale a la promoción del concepto genealógico de raza católica), Sabino Arana daba otra vuelta de tuerca al casticismo español y lo volvía contra los propios españoles, al defender que los Fueros de los euzkos, todos ellos "cristianos viejos" desde tiempo inmemorial, prohibían establecerse en tierra vasca a quien no fuera euzko porque consideraban a todos los españoles sospechosos de tener, más lejos o más cerca, algún antepasado moro o judío responsable de la irremediable infección religiosa de su sangre y de su raza.

Lo curioso es que esta tesis extremista de Sabino Arana tiene una larga tradición española:

La tesis de la contaminación total e irremediable de la sangre española fue propagada en España mediante los llamados "libros verdes" o "libros del becerro", compilaciones genealógicas de linajes 'tocados' que empezaron a circular en España desde principios del siglo XVI (Stallaert 2004).

En tiempos de Felipe III, en su Discurso acerca de la justicia y buen gobierno de España en los estatutos de limpieza de sangre, el fraile dominico Agustín Salucio (1975) propugnó una reforma de éstos. Como ha señalado Stallaert:

Curiosamente, el argumento de peso que esgrime Salucio a favor de la limitación no se basa en que al cabo de más de un siglo de actuación inquisitorial y vigencia de los estatutos de limpieza de sangre, se puede suponer que el país ha quedado depurado de elementos impuros. Al contrario, Salucio opta por la lógica casticista obsesionada con la fuerza genéticamente dominante de cualquier gota de sangre judía o musulmana. Advierte que si las investigaciones de pureza de sangre realmente pudieran llevarse a cabo sin limitaciones prácticas, lo que se descubriría sería que todos los españoles llevan alguna parte, por infima que fue$r a$, de sangre manchada. Es decir, Salucio pide la reforma alegando que el proyecto étnico que España se había propuesto estaba desde los inicios destinado al fracaso al haberse adoptado demasiado tarde las medidas de protección étnica como la Inquisición y los estatutos de limpieza de sangre. ¡El judío, los españoles ya lo llevaban dentro! ( $i b i d$.).

Con independencia de que se piense con Agustín Salucio y con Sabino Arana que sólo los euzkos son de pura raza católica, limpios de sangre y "cristianos viejos" y que todos los españoles son de raza impura, mezcla de moro o judío y "racialmente" paganos o herejes, o bien se acepte, con la Santa Inquisición, que no todos los españoles tienen sangre mora o judía sino sólo los marranos y los moriscos, lo realmente significativo es que esa concepción genealógica de la raza católica (española o sólo vasca) constituye un claro préstamo ideológico del judaísmo a la peculiar versión católico-española del cristianismo que profesa la Santa Inquisición y la España de los Reyes Católicos. Es decir, el origen último del concepto de raza vas- 
ca en Sabino Arana no es otro que el concepto de pueblo judio del judaísmo rabínico filtrado a través del concepto de raza católico-española del casticismo español.

\section{BIBLIOGRAFÍA CITADA}

Arana Goiri, S. de. 1965. Obras completas de Arana-Goiri'tar Sabin. Buenos Aires: Sabindiar-Batza.

Aranzadi, J. 1981. Milenarismo vasco. Madrid: Taurus.

Aranzadi, J. 2001. El escudo de Arquíloco. Sobre mesías, mártires y terroristas, en 2 tomos. Madrid: Antonio Machado Libros.

Caro Baroja, J. 1977. Los pueblos del norte. San Sebastián: Txertoa.

Dumont, L. 1966. Homo hierarchicus: esssai sur le système des castes. París: Gallimard.

Echave, B. de. 1971 [1607]. Discursos de la Antigüedad de la Lengua Cántabra Bascongada. Bilbao: La Gran Enciclopedia Vasca.

Fernández Albadalejo, P. 1977. "Manuel Larramendi, la particular historia de Guipúzcoa". Saioak, Revista de Estudios Vascos 1: 148-157.

García Morente, M. 1943. Ideas para una filosofía de la Historia de España. Madrid: Universidad de Madrid.

Netanyahu, B. 1999. Los origenes de la Inquisición en la España del siglo XV. Barcelona: Crítica.

Orr, A. 1994. Israel: Politics, Myths and Identity Crises. Londres: Pluto Press.

Portillo Valdés, J. M. 1998. "República de hidalgos. Dimensión política de la hidalguía universal entre Vizcaya y Guipúzcoa”, en J. R. Díaz de Durana y Ortiz de Urbina (eds.), La lucha de Bandos en el País Vasco: de los Parientes Mayores a la hidalguia universal: 425-437. Bilbao: Universidad del País Vasco.

Poza, A. de. 1997. Fuero de hidalguía. Ad pragmaticas de Toro et Tordesillas. Edición y estudio introductorio de C. Muñoz de Bustillo. Bilbao: Universidad del País Vasco.

Salucio, A. 1975 [1599]. Discurso acerca de la justicia y buen gobierno de España en los estatutos de limpieza de sangre. Ed. facsímil. Cieza (Murcia): La fonte que mana y corre.

Shahak, I. 1994. Jewish History, Jewish Religion. Londres: Pluto Press.

Stallaert, Ch. 1998. Etnogénesis y etnicidad. Una aproximación histórico-antropológica al casticismo. Barcelona: Proyecto A Ediciones.

Stallaert, Ch. 2004. "La España de la limpieza de sangre. Una interpretación antropológica de una reacción étnica". Intervención, no publicada, en el Curso de Verano de la Universidad de Castilla-La-Mancha sobre El antijudaísmo en España (Toledo, 6-9 de septiembre de 2004).

Stallaert, Ch. 2006. Ni una gota de sangre impura. La España inquisitorial y la Alemania nazi cara a cara. Barcelona: Galaxia Gutemberg.

Zugaza, L. 1976. Fuero Nuevo de Vizcaya. Introducción de A. Celaya Ibarra. Durango (Vizcaya): Leopoldo Zugaza, S. L.

Fecha de recepción: 30 de abril de 2009

Fecha de aceptación: 17 de julio de 2009 